\title{
Adrenergic Calcium Signaling in Astrocyte Networks within the Hippocampal Slice
}

\author{
Steven Duffy and Brian A. MacVicar \\ Department of Neuroscience, University of Calgary, Calgary, Canada T2N 4N1
}

Norepinephrine (NE) and glutamate (Glu) initiate intracellular calcium $\left(\left[\mathrm{Ca}^{2+}\right]_{i}\right)$ transients, oscillations, and intracelIular $\left[\mathrm{Ca}^{2+}\right]$, waves in cultured astrocytes. To further elucidate the significance of NE- and Glu-evoked astrocytic $\left[\mathrm{Ca}^{2+}\right]_{i}$ signaling to neuron-astrocyte communication in the mature CNS, $\left[\mathrm{Ca}^{2+}\right]_{i}$ of astrocyte networks within hippocampal slices (P21-42) was measured during bath application of NE and Glu receptor agonists. Astrocytes in stratum radiatum were identified by highly negative membrane potentials $(75 \pm 3 \mathrm{mV})$, absence of action potentials, and dye coupling following intracellular injection of the $\left[\mathrm{Ca}^{2+}\right]-$ sensitive dye calcium orange. NE $(2-100 \mu \mathrm{M})$ evoked $\left[\mathrm{Ca}^{2+}\right]_{i}$ increases ( 7 of 8 slices, 24 of 24 cells in responding slices) characterized by an initial rise, 20-50 sec to peak, followed by a slower return to baseline (over $\approx 8 \mathrm{~min}$ ). The $\alpha_{1}$-agonist phenylephrine (PE) (10-100 $\mu \mathrm{M})$ evoked complex $\left[\mathrm{Ca}^{2+}\right]_{i}$ signals (22 of 26 slices, 90 of 90 cells in responding slices) composed of both a prolonged component (5.1 $\pm 1.8 \mathrm{~min})$, synchronized in neighboring cells, and multiple, mainly asynchronous $\left[\mathrm{Ca}^{2+}\right]_{i}$ spikes $(25.0 \pm 11.6 \mathrm{sec})$. PE responses were completely blocked by the $\alpha_{1}$-antagonist prazosin (200 nM, $n=4$ slices), but not by the $\alpha_{2}$-antagonist yohimbine ( $n=3$ slices). The $\alpha_{2}$-agonist clonidine (10-100 $\mu \mathrm{M})$ did not increase $\left[\mathrm{Ca}^{2+}\right]_{i}(n=4$ slices $) . \alpha_{1}$-mediated $\left[\mathrm{Ca}^{2+}\right]_{\text {i }}$ transients were observed after removal of extracellular $\left[\mathrm{Ca}^{2+}\right]_{0}$ ( $n=8$ of 9 slices), indicating PE-induced $\mathrm{Ca}^{2+}$ release from intracellular stores. Adrenergic responses were mediated by $\alpha_{1}$-receptors localized to astrocytes because PE and NE increased $\left[\mathrm{Ca}^{2+}\right]_{i}$ of acutely isolated hippocampal astrocytes. Glu $(0.75-2.0 \mathrm{~mm})$ did not increase astrocytic $\left[\mathrm{Ca}^{2+}\right]_{i}$ in slices (0 of 7 ), even in the presence of the Glu uptake inhibitor L-trans-pyrrollidine-2,4-dicarboxylic acid (PDC) (0 of 5 slices), or in acutely isolated astrocytes ( 0 of 7 cells). The metabotropic agonist t-ACPD (30 or $50 \mu \mathrm{M})$ did not increase astrocytic $\left[\mathrm{Ca}^{2+}\right]$, in hippocampal slices $(0$ of 5$)$, while kainate $(200 \mu \mathrm{M}$ or $1 \mathrm{~mm})$ induced brief (1-2 $\mathrm{min})\left[\mathrm{Ca}^{2+}\right]$, increases only rarely (2 of 8 applications in 6 slices). These results support a primary role of NE

\footnotetext{
Received Jan. 5, 1995; revised Apr. 5, 1995; accepted Apr. 7, 1995.

We thank Drs. D. D. Fraser, J. Plant, and S. Weiss for critically reviewing the manuscript. S. Duffy was supported by Alberta Heritage for Medical Research (AHFMR) and W. H. Davies scholarships. B. A. MacVicar is an AHFMR scientist and Ciba-Geigy chair for schizophrenia research. This work was supported by the Medical Research Council (Canada) and an equipment grant from AHFMR.

Correspondence should be addressed to Dr. B. A. MacVicar, Department of Neuroscience, University of Calgary, 3330 Hospital Drive NW, Calgary, Alberta, Canada $12 \mathrm{~N}-4 \mathrm{~N} 1$.

Copyright (C 1995 Society for Neuroscience $0270-6474 / 95 / 155535-16 \$ 05.00 / 0$
}

release and $\alpha_{1}$-adrenoceptor stimulation in neuron-astrocyte communication in the mature CNS.

[Key words: astrocyte, adrenergic receptor, intracellular calcium, glutamate receptor, calcium orange]

There is growing evidence that astrocytes and neurons communicate by means of neurotransmitters, and that intracellular calcium $\left(\left[\mathrm{Ca}^{2+}\right]_{i}\right)$ may be an important second messenger in neuron-to-astrocyte signaling. Astrocytes in primary culture, explant culture, and neonatal tissue all express a multitude of neurotransmitter receptors that trigger increases in $\left[\mathrm{Ca}^{2+}\right]_{i}$ and propagating $\left[\mathrm{Ca}^{2+}\right]_{i}$ waves upon exogenous transmitter application or nerve stimulation (Finkbeiner, 1993; Murphy, 1993; for recent reviews, Cornell-Bell et al., 1990; Dani et al., 1992; Finkbeiner, 1992; Jahromi et al., 1992; Kriegler and Chiu, 1993; Jabs et al., 1994; Nedergaard, 1994; Parpura et al., 1994). In turn, astrocytic $\left[\mathrm{Ca}^{2+}\right]_{i}$ signals and waves can evoke $\left[\mathrm{Ca}^{2+}\right]_{i}$ signals in neurons (Nedergaard, 1994; Parpura et al., 1994). While observations in culture suggest $\left[\mathrm{Ca}^{2+}\right]_{i}$-dependent bidirectional communication between astrocytes and neurons, there is little direct evidence for $\left[\mathrm{Ca}^{2+}\right]_{i}$ signals in fully differentiated astrocytes. Moreover, the plasticity of astrocyte phenotype under different culture conditions (Juurlink and Hertz, 1985; Barres et al., 1989) has cast doubt on the reliability of astrocytes in cell culture as a faithful reflection of astrocyte phenotype in vivo. What is required, therefore, is a description of the transmitter-dependent $\left[\mathrm{Ca}^{2+}\right]_{i}$ signaling properties of astrocytes within intact, uncultured brain tissue. To this end, we have made microfluorometric $\left[\mathrm{Ca}^{2+}\right]_{i}$ measurements from astrocytes within mature hippocampal slices iontophoretically loaded with the $\left[\mathrm{Ca}^{2+}\right]$ indicator calcium orange, and from acutely isolated hippocampal astrocytes loaded with fura- 2 or indo-1.

Norepinephrine (NE) and glutamate (Glu) may be of particular importance in astrocytic $\left[\mathrm{Ca}^{2+}\right]_{i}$ signaling and neuron-to-glia communication. Astrocytes express adrenergic receptors in situ (Salm and McCarthy, 1989; Aoki, 1992), and adrenergic synapses have been observed adjacent to astrocytic processes (Seguela et al., 1990; Ridet et al., 1993). Similarly, astrocytes express glutamate receptors in situ (Somogyi et al., 1990; Clark and Mobbs, 1992; Muller et al., 1992; Kriegler and Chiu, 1993; Jabs et al., 1994; Steinhauser et al., 1994; Porter and McCarthy, 1995). In culture, adrenergic and glutamatergic stimulation may increase $\left[\mathrm{Ca}^{2+}\right]_{i}$ through multiple pathways. $\alpha_{1}$-adrenergic receptors and trans-(土)-1-amino-1,3-cyclopentanedicarboxylic acid (t-ACPD)-selective glutamate receptors stimulate $\left[\mathrm{Ca}^{2+}\right]_{i}$ increases through the phospholipase $\mathrm{C}$ (PLC)-mediated generation of $\mathrm{IP}_{3}$ (adrenergic: Pearce et al., 1985; Salm and McCarthy, 1990; Delumeau et al., 1991; El-Etr et al., 1992; glutamate: Pearce et al., 1986; Milani et al., 1989; Ahmed et al., 1990; 
Glaum et al., 1990; Nicoletti et al., 1990; de Barry et al., 1991). As well, $\alpha_{1}$-adrenergic stimulation (Bowman and Kimelberg, 1987; Enkvist et al., 1989) and ionotropic glutamatergic stimulation (Bowman and Kimelberg, 1984) depolarize astrocytes, which may promote $\left[\mathrm{Ca}^{2+}\right]$ influx through voltage-gated $\mathrm{Ca}$ channels (Duffy and MacVicar, 1994). Isoforms of the AMPA/ kainate receptor channel show significant $\left[\mathrm{Ca}^{2+}\right]$ permeability and so can mediate direct $\left[\mathrm{Ca}^{2+}\right]$ influx (Muller et al., 1992; Kriegler and Chiu, 1993; Jabs et al., 1994). Finally, the $\alpha_{2}$-adrenergic agonists can also increase astrocytic $\left[\mathrm{Ca}^{2+}\right]_{i}$ (Salm and McCarthy, 1990; Zhao et al., 1992), although the signaling pathway involved has not been determined.

The results presented here indicate that astrocytes within intact hippocampal slices respond to $\mathrm{NE}$ and $\alpha_{1}$-receptor agonists with increases in $\left[\mathrm{Ca}^{2+}\right]_{i}$. In contrast, neither glutamate nor glutamate receptor agonists were effective in elevating astrocytic $\left[\mathrm{Ca}^{2+}\right]_{i}$.

\section{Materials and Methods}

Treparation and maintenance of hippocampal slices. Transverse hippocampal slices $(450 \mu \mathrm{m})$ were obtained from P21-P42 Sprague-Dawley rats using a manual tissue chopper. Slices were washed in artificial cerebrospinal fluid (aCSF) containing (mM) $124 \mathrm{NaCl}, 5 \mathrm{KCl}, 26$ $\mathrm{NaHCO}_{3}, 1.3 \mathrm{MgCl}_{2}, 2 \mathrm{CaCl}_{2}, 10$ glucose, $\mathrm{pH} 7.35-7.40$, and stored within an aerated $\left(95 \% \mathrm{O}_{2}, 5 \% \mathrm{CO}_{2}\right)$, humidified interface chamber. This aCSF was also used as the control saline for all $\left[\mathrm{Ca}^{2+}\right]_{i}$ imaging experiments. Before dye injection, individual slices were transferred to a submerged perfusion bath mounted on the stage of an inverted epifluorescence microscope (Axiovert 10, Zeiss). The bath was superfused with room temperature aCSF $\left(21-24^{\circ} \mathrm{C}\right)$ at a rate of $\sim 0.5-0.6 \mathrm{ml} / \mathrm{min}$ using a peristaltic pump (Gilson). For zero extracellular $\left[\mathrm{Ca}^{2+}\right]_{0}$ aCSF, $\mathrm{CaCl}_{2}$ was replaced by $\mathrm{MgCl}_{2}$, and $40-100 \mu \mathrm{M}$ of the $\left[\mathrm{Ca}^{2+}\right]$ chelator ethylene glycol-bis( $\beta$-aminoethylether) $N, N, N^{\prime}, N^{\prime}$-tetraacetic acid (EGTA) added so that final $\left[\mathrm{Ca}^{2+}\right]_{o}$ was $<<16 \mathrm{nM}$ (as determined by fura-2 calibration). aCSF containing $50 \mathrm{~mm}\left[\mathrm{~K}^{+}\right]$, was made by equimolar substitution of $\mathrm{KCl}$ for $\mathrm{NaCl}$. All superfusion solutions used in calcium orange experiments also contained 10 or $20 \mu \mathrm{M}$ of the heavy metal chelator tetrakis(2-pyridylmethyl)ethylenediamine (TPEN), since trace amounts of these cations can interfere with dye fluorescence (Arslan et al., 1985). All superfusates used in acute isolation experiments also contained $40 \mathrm{~mm}$ sucrose.

lontophoretic loading of hippocampal astrocytes with calcium orange. For iontophoretic injection, a microelectrode was filled with 100 $\mathrm{mm} \mathrm{K}$-acetate plus $5 \mathrm{~mm}$ calcium orange, tetrapotassium salt. Final electrode resistance ranged from 75 to $150 \mathrm{M} \Omega$ For recording changes in astrocytic membrane potential $\left(E_{m}\right)$ in response to $\mathrm{PE}$, cells were impaled with lower resistance electrodes containing $2 \mathrm{M} \mathrm{K}$-acetate or 1 $\mathrm{M} \mathrm{KCl}$ (electrode resistance was $30-50 \mathrm{M} \Omega$ ). Electrodes were mounted to the headstage of an amplifier (Neurodata Instrument $\mathrm{Co}$.) with output gain of either 10 or 100 . This output was filtered at $100 \mathrm{kHz}$ low pass and displayed on a digital oscilloscope (Nicole 2090). Astrocytes were identified by their unique electrophysiology (highly negative $E_{m}$, no impalement, or stimulus-evoked action potentials) and by dye coupling following injection of calcium orange. Only cells $\approx 30-100 \mu \mathrm{m}$ below the top cut surface were loaded, as deeper cells were beyond the working distance of the objective lens, while more superficial cells had lower resting membrane potentials $(\approx-60 \mathrm{mV})$ indicative of tissue damage. A steady hyperpolarizing current $(-0.2$ to $-0.5 \mathrm{nA})$ with superimposed square current pulses $(-0.4$ to $-1.0 \mathrm{nA}, 200-500 \mathrm{msec}$ duration, $1 \mathrm{~Hz})$ passed through the electrode was used to load astrocytes with calcium orange. The $E_{m}$ was monitored continuously during dye injection and did not change appreciably. A minimum of 5-10 min of injection was required to load a cluster of cells sufficiently for $\left[\mathrm{Ca}^{2+}\right]_{i}$ imaging. Dye injection was continued for as long as electrode resistance remained stable. In some cells, an $I-V$ plot was generated by passing hyperpolarizing and depolarizing currents through the electrode. The $I-V$ pulse paradigm was controlled by a 386 microcomputer (Packard-Bell) using the TL-125 interface and pCLAMP software (Axon Instrument Co).

Fluorometric calcium imaging in hippocampal slices. Following dye loading, the slice was turned over so that the loaded cells were within the working distance of the objective (50X Achroplan, Zeiss), and the slice was secured with small pieces of platinum wire. Excitation light was provide by a $75 \mathrm{~W}$ Xenon arc lamp (Zeiss) coupled to an electronic shutter (Uniblitz T132) controlled by the imaging software (AXON IMAGING WORKBENCH, Axon Instruments). Calcium orange is a rhodamine derivative, with excitation and emission maxima at $550 \mathrm{~nm}$ and 580 $\mathrm{nm}$, respectively, so standard rhodamine filters (Omega Optical) were used to visualize dye-loaded astrocytes. A neutral density filter (o.d. 0.8 ; Newport Corp.) was placed in the excitation path. Fluorescence emission increases upon $\left[\mathrm{Ca}^{2+}\right]$ binding, so an increase in fluorescence emission is indicative of increasing $\left[\mathrm{Ca}^{2+}\right]_{i}$. Changes in fluorescence emission were recorded using a Kohu $6500 \mathrm{CCD}$ camera coupled to an image intensifier (KS-1381, Video Scope). Video frames were digitized and 32 frames averaged by an eight-bit A/D board (Data Translation, DT 2867) controlled by AXON IMAGING WORKBENCH software on a 486 microcomputer (Atman). The imaging software also controlled the electronic shutter in the excitation path, which remained open only for the period of frame acquisition $(960 \mathrm{msec})$. A few images were obtained using a confocal laser scanning microscope (Meridian) and the imaging system described above. The image acquisition rate ranged from one image every $2-15 \mathrm{sec}$. Changes in dye fluorescence were quantified by averaging the pixel values (between $0-255$ ) within a box overlapping the image of the astrocyte cell body. Because calcium orange is a nonratiometric dye with a relatively small fluorescence emission increase $\left(\approx 4-5\right.$-fold from 0 to $39.8 \mu \mathrm{M}\left[\mathrm{Ca}^{2+}\right]_{i}$; Molecular Probes Handbook of Fluorescent Probes and Research Chemicals, 1994), fluorescence images could not be calibrated for absolute or relative changes in $\left[\mathrm{Ca}^{2+}\right]_{i}$. Thus, changes in fluorescence are expressed in eight-bit pixel values and denoted as $F$ or $\Delta F$. In many experiments, a steady continuous fluorescence decrease was observed which was due to continuous passage of dye through the syncytium and to photobleaching. For clarity of presentation, this decrease has been compensated by a linear extrapolation:

$$
\Delta F=\left\{\left[-\left(F_{n}-F_{1}\right) /\left(t_{n}-t_{1}\right)\right] t_{i}+F_{i}\right\}-F_{1}
$$

where $F_{i}$ is the uncorrected fluorescence at time $t_{i}$, and $F_{1}$ and $F_{n}$ are the first and last $F$ values at times $t_{1}$ and $t_{n}$.

Fluorometric calcium imaging of acutely isolated astrocytes. The methods for acute enzymatic isolation of astrocytes and fluorometric $\left[\mathrm{Ca}^{2+}\right]_{i}$ imaging were identical to those described previously (Duffy and MacVicar, 1994). Briefly, slices were digested in an enzyme solution containing control aCSF plus the protease papain ( 24 units $/ \mathrm{ml})$, the papain activator L-cysteine ( $1 \mathrm{mg} / 100$ papain units), and the glutamate antagonist kynurenic acid $(1 \mathrm{~mm})$. Slices were added to this solution and stirred in a spinner flask (Belco) for $60-80 \mathrm{~min}$ at $32^{\circ} \mathrm{C}$. Upon removal, slices were washed in fresh aCSF and stored in aerated aCSF until used. For cell isolation and $\left[\mathrm{Ca}^{2+}\right]$-sensitive dye loading, the CAl3 regions of enzyme-treated slices were dissected free using a scalpel blade, and these small tissue sections were added to a solution of Dulbecco's Modified Eagles Medium (DMEM) containing $16.6 \mu \mathrm{M}$ fura-2 or indo-1 (predissolved in $10 \mu$ l DMSO with $10 \%$ pluronic acid), $1 \mathrm{~mm}$ kynurenic acid, and $0.3 \mathrm{mg}$ leupeptine (an inhibitor of $\left[\mathrm{Ca}^{2+}\right]$-activated proteases). Enzyme-treated tissue was then passed repeatedly through fire-polished pasteur pipettes, and the resulting cell suspension was al-

Figure 1. Electrophysiological properties of a hippocampal astrocyte $(A)$, neuron $(B)$, and staining pattern following iontophoretic injection of calcium orange into electrophysiologically defined astrocytes $(C-E)$. A, Cell with $E_{m}$ of $-75 \mathrm{mV}$ was impaled with an electrode containing $5 \mathrm{~mm}$ calcium orange, tetrapotassium salt. One hundred and forty millisecond currents pulses, ranging in amplitude from $-0.8 \mathrm{nA}$ to $1.4 \mathrm{nA}$ in $0.2 \mathrm{nA}$ increments, were passed through the electrode and the change in $E_{m}$ monitored. The cell showed no electrogenesis during depolarizing or following hyperpolarizing current pulses. $B$, Depolarization of neurons by current injection $(0.4 \mathrm{nA})$ through a calcium orange-filled electrode resulted in a train of action potentials. $C$, Following approximately $10 \mathrm{~min}$ of dye injection into the cell shown in $A$, many stained cell bodies were visible. $D$, A higher magnification image showing stained cells at the center of the cluster shown in $C$. $E$, From another slice, dye-coupled astrocytes imaged with a confocal microscope. 

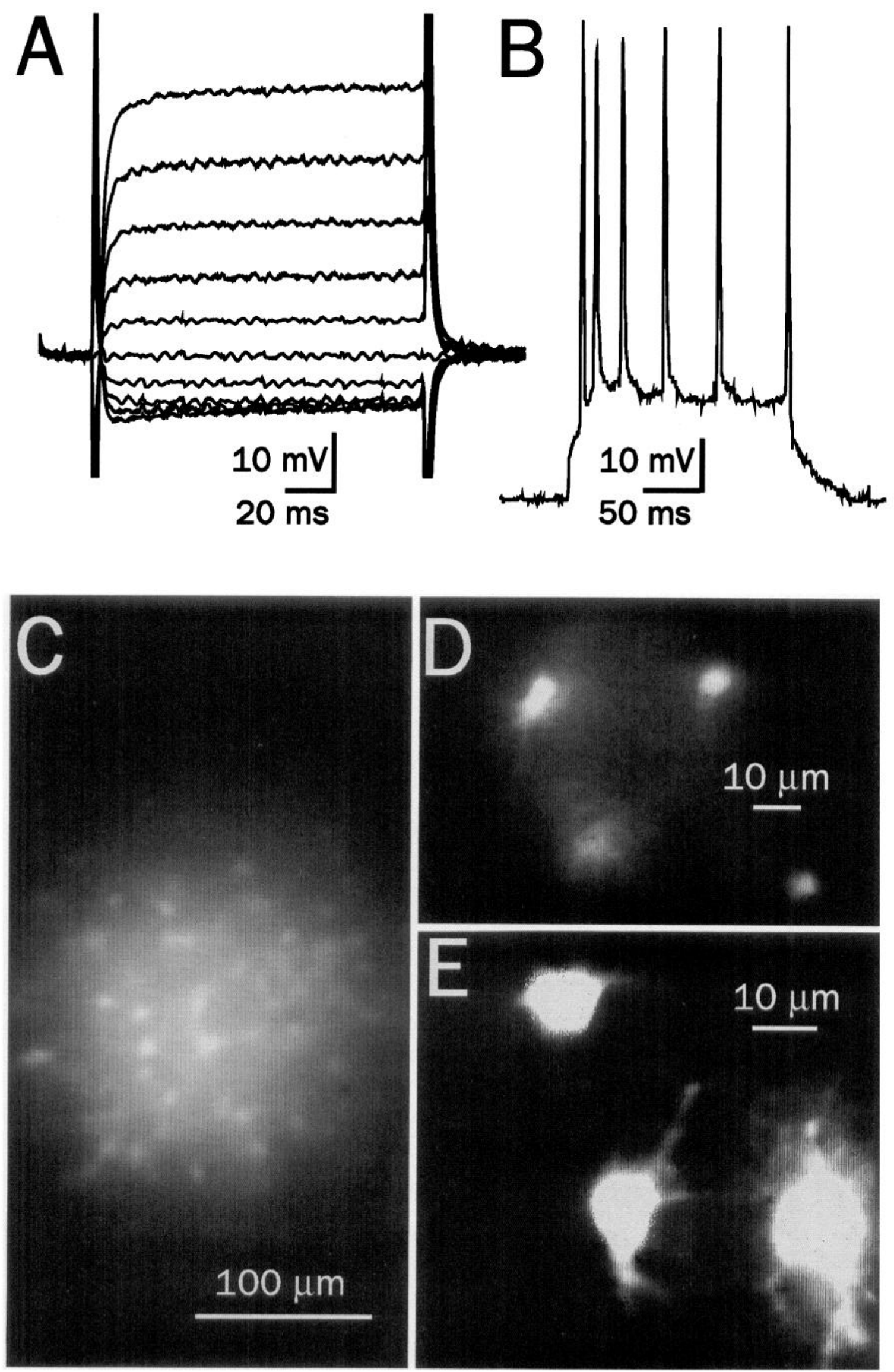
lowed to settle for $\approx 20 \mathrm{~min}$ on poly-L-lysine-coated coverslips on the stage of an epifluorescence microscope (Zeiss IM). The calcium measurement systems have been described previously (MacVicar et al., 1991; Duffy and MacVicar, 1994).

Chemicals. All standard salts were purchased from Fisher (Fair Lawn, NJ), Sigma (St. Louis, MO), or BDH (Toronto, Ontario). Calcium-sensitive dyes (calcium orange, fura-2, indo-1), pluronic acid, and TPEN were purchased from Molecular Probes (Eugene, OR). Phenylephrine (PE), glutamate, kainate, papain, leupeptin, kynurenic acid, sodium metabisulfite, and cysteine were purchased from Sigma. Norepinephrine, clonidine, prazosin, yohimbine, trans-( \pm )-1-amino-1,3-cyclopentanedicarboxylic acid (t-ACPD) and L-trans-pyrrollidine-2,3-dicarboxylic acid (PDC) were purchased from RBI (Natick, MA). Norepinephrine and phenylephrine were added to superfusate from fresh $100 \mathrm{~mm}$ stock solutions containing $5 \mathrm{mg} / \mathrm{ml}$ of the antioxidant sodium metabisulfite. Yohimbine, prazosin, and TPEN were predissolved in ethanol from stock concentrations of $5 \mathrm{mM}, 1 \mathrm{mM}$, and $1 \mathrm{~mm}$, respectively, and stored at $-20^{\circ} \mathrm{C}$. Final ethanol concentrations in superfusates were $0.01-0.03 \%$. Glutamate was added either from $500 \mathrm{~mm}$ stocks (in water or $1 \mathrm{~N}$ $\mathrm{NaOH}$ ) or directly. $\mathrm{t}$-ACPD was added from 25-50 ram stocks and kainate was added directly to aCSF.

\section{Results}

\section{Iontophoretic injection of astrocytes with calcium orange}

Two electrophysiologically distinct cell populations were observed upon impalement with dye-filled microelectrodes. Pyramidal neurons, encountered in stratum pyramidale, showed trains of action potentials upon impalement (impalement discharge), resting potentials between -40 and $-60 \mathrm{mV}$, and trains of action potentials during depolarizing current pulses (Fig. 1B). Astrocytes, impaled mainly in the radiatum of CA1-3, had more negative $E_{m}(75 \pm 3 \mathrm{mV}, n=36)$, and no impalement- or stimulus-evoked action potentials (Fig. 1A). In some slices, we determined the current-voltage $(I-V)$ relationship in astrocytes during dye loading. In response to $140 \mathrm{msec}$ current pulses ranging from -0.8 to $1.4 \mathrm{nA}$, the $I-V$ was either linear $(n=7$, average input resistance $R_{\text {in }}=45.9 \mathrm{M} \Omega$ ) or inwardly rectifying ( $n=7$, $R_{\text {in }}=24.4 \mathrm{M} \Omega$ for hyperpolarizing currents, $R_{\mathrm{in}}=46.6 \mathrm{M} \Omega$ for depolarizing pulses). Following 5-20 min of iontophoretic dye injection into one cell, a cluster of dye-loaded cells with small round cell bodies (8-10 $\mu \mathrm{m}$ in diameter) was observed (Fig. $1 C-E$ ). For the experiments described below, 2-7 cells were visualized within a single field at a single plane of focus. Iontophoretic ejection of dye into the interstitium for $0.5 \mathrm{hr}$ did not result in this staining pattern ( $n=2$, not shown). In a few experiments, dye injection into presumed astrocytes resulted in the staining of a single uncoupled cell with a larger cell body and thick processes. These cells where not positively identified but could have been the noncoupled hippocampal astrocytes previously described in vitro (Sontheimer et al., 1991) or oligodendrocytes. They were not studied further.

\section{Effect of norepinephrine on $\left[\mathrm{Ca}^{2+}\right]_{\mathrm{i}}$ of astrocytes}

Bath application of the adrenergic agonist norepinephrine (NE) $(2-100 \mu \mathrm{M})$ increased $\left[\mathrm{Ca}^{2+}\right]_{i}$ of astrocytes within hippocampal slices, as indicated by the increase in calcium orange fluorescence emission $(F)$ (Fig. $2 B ; n=7$ of 8 slices). In these responding slices, all visible astrocytes $(n=24$ of 24) exhibited a $\left[\mathrm{Ca}^{2+}\right]_{i}$ signal consisting of an initial rise to peak within 20
$50 \mathrm{sec}$, followed by a slower return to baseline upon washout (Fig. $2 C$ ). Responses were reproducible at least twice in all slices (inset, Fig. $2 C$ ). The minimum bath concentration of NE necessary to elicit a response was $2-10 \mu \mathrm{M}$ (Fig. 3A,B). The duration of the $\left[\mathrm{Ca}^{2+}\right]_{i}$ response due to 2.5-3.0 min applications of $\mathrm{NE}$ ranged from 3.9 to $16.8 \mathrm{~min}$ (average $8.2 \mathrm{~min}$ for all concentrations; $9.8 \mathrm{~min}$ for $50 \mu \mathrm{M}, n=4 ; 6.8 \mathrm{~min}$ for $10 \mu \mathrm{M}, n=$ 3).

\section{Pharmacology of adrenergic-evoked $\left[\mathrm{Ca}^{2+}\right]_{\mathrm{i}}$ signals in astrocytes}

To determine the role of adrenergic receptor subtype(s) in astrocytic $\left[\mathrm{Ca}^{2+}\right]_{i}$ signaling, subtype-specific agonists and antagonists were applied. The $\alpha_{1}$-adrenergic agonist phenylephrine (PE) $(10-100 \mu \mathrm{M})$ also elicited $\left[\mathrm{Ca}^{2+}\right]_{i}$ increases (22 of 26 slices, 90 cells; Fig. 4A). The kinetics of these increases were, however, considerably more complex than those evoked by NE. Like NE responses, $\mathrm{PE}$ responses consisted of prolonged $\left[\mathrm{Ca}^{2+}\right]_{i}$ increases (mean duration $5.1 \pm 1.8 \mathrm{~min}$ ). In addition, the majority of astrocytes exhibited faster $\left[\mathrm{Ca}^{2 !}\right]_{i}$ spikes superimposed on the sustained component ( 66 of 90 cells, mean duration $25.0 \pm 11.6$ sec). Like NE responses, the prolonged phase was always synchronized in neighboring cells, while $\left[\mathrm{Ca}^{2+}\right]_{i}$ spikes were mainly asynchronous (Fig. $4 B$ ). For example, in a sample of 90 large spikes, 67\% (60 of 90) were not correlated with spike events in any other visible astrocyte, while the remaining 30 spikes were observed as 15 spike pairs (simultaneous spikes in two cells) that were asynchronous with $\left[\mathrm{Ca}^{2+}\right]_{i}$ changes in all remaining cells in the field of view. A sequential series of fluorometric images during PE stimulation demonstrates the complexity of PE-evoked $\left[\mathrm{Ca}^{2+}\right]_{i}$ signaling in three closely spaced cells (Fig. $4 A$ ). The top cell (cell 1) undergoes rhythmic $\left[\mathrm{Ca}^{2+}\right]_{i}$ oscillations while the cell bottom right (cell 3 ) shows virtually no spiking activity (Fig. 4B).

Preapplication of specific $\alpha_{1}$ - and $\alpha_{2}$-receptor antagonists revealed that PE responses were mediated by $\alpha_{1}$-receptors. PEstimulated $\left[\mathrm{Ca}^{2+}\right]_{i}$ increases were never observed in the presence of $200 \mathrm{nM}$ of the $\alpha_{1}$-antagonist prazosin (PRZ) ( $n=0$ of 4; Fig. $5 A$ ) and only once ( 1 of 4 ) in 50 or $100 \mathrm{nM}$ PRZ. Blockade of PE-mediated $\left[\mathrm{Ca}^{2+}\right]_{i}$ increases by PRZ was not reversible in slices, probably because of the slow washout of this lipophilic substance from brain tissue (Lullmann et al., 1979). PRZ inhibition was, however, specific for adrenergic-mediated $\left[\mathrm{Ca}^{2+}\right]_{i}$ signaling as a reversible $\left[\mathrm{Ca}^{2+}\right]_{i}$ response was observed in response to depolarization with $50 \mathrm{~mm}\left[\mathrm{~K}^{+}\right]_{o}$ (Fig. $5 A ; n=20$ of 24 slices). This suggests that PRZ treatment did not exert nonspecific effects on astrocytic $\left[\mathrm{Ca}^{2+}\right]_{i}$ metabolism. Voltage-dependent $\left[\mathrm{Ca}^{2+}\right]_{i}$ increases in astrocytes within hippocampal slices are examined in detail elsewhere (S. Duffy and B. A. MacVicar, unpublished observations).

$\alpha_{2}$-receptor stimulation has been shown to elicit $\left[\mathrm{Ca}^{2+}\right]_{i}$ increases in cultured astrocytes. To detcrmine if $\alpha_{2}$ stimulation contributed to the NE- or PE-evoked $\left[\mathrm{Ca}^{2+}\right]_{i}$ increase observed here, the effects of $\alpha_{2}$-agonists and -antagonists on $\left[\mathrm{Ca}^{2+}\right]_{i}$ were assessed. The $\alpha_{2}$-agonist clonidine $(10-100 \mu \mathrm{M})$ did not evoke

Figure 2. Norepinephrine $(N E)$ increased astroglial $\left[\mathrm{Ca}^{2+}\right]_{i}$. A, Digitized image of resting fluorescence emission from a field with seven dyecoupled astrocytes. $B$, Bath application of $50 \mu \mathrm{M} \mathrm{NE}$ triggered an increase in fluorescence emission, indicative of an increase in [Ca $\left.{ }^{2+}\right]_{i}$, in all cells. $C$, The time course of the change in fluorescence emission $(F)$ in the two cells demarcated as 1 and 2 . The rapid increase and slow recovery of $\left[\mathrm{Ca}^{2+}\right]_{i}$ were synchronous in adjacent cells. A subsequent application of $\mathrm{NE}$ also elicited a $\left[\mathrm{Ca}^{2+}\right]_{l}$ increase (inset). Calibration: color bar in $A$ and $B$, bottom purple (pixel value 50 ) to top red (pixel value 140); inset in $C, \Delta F=20$ pixel units, 60 sec. 
A

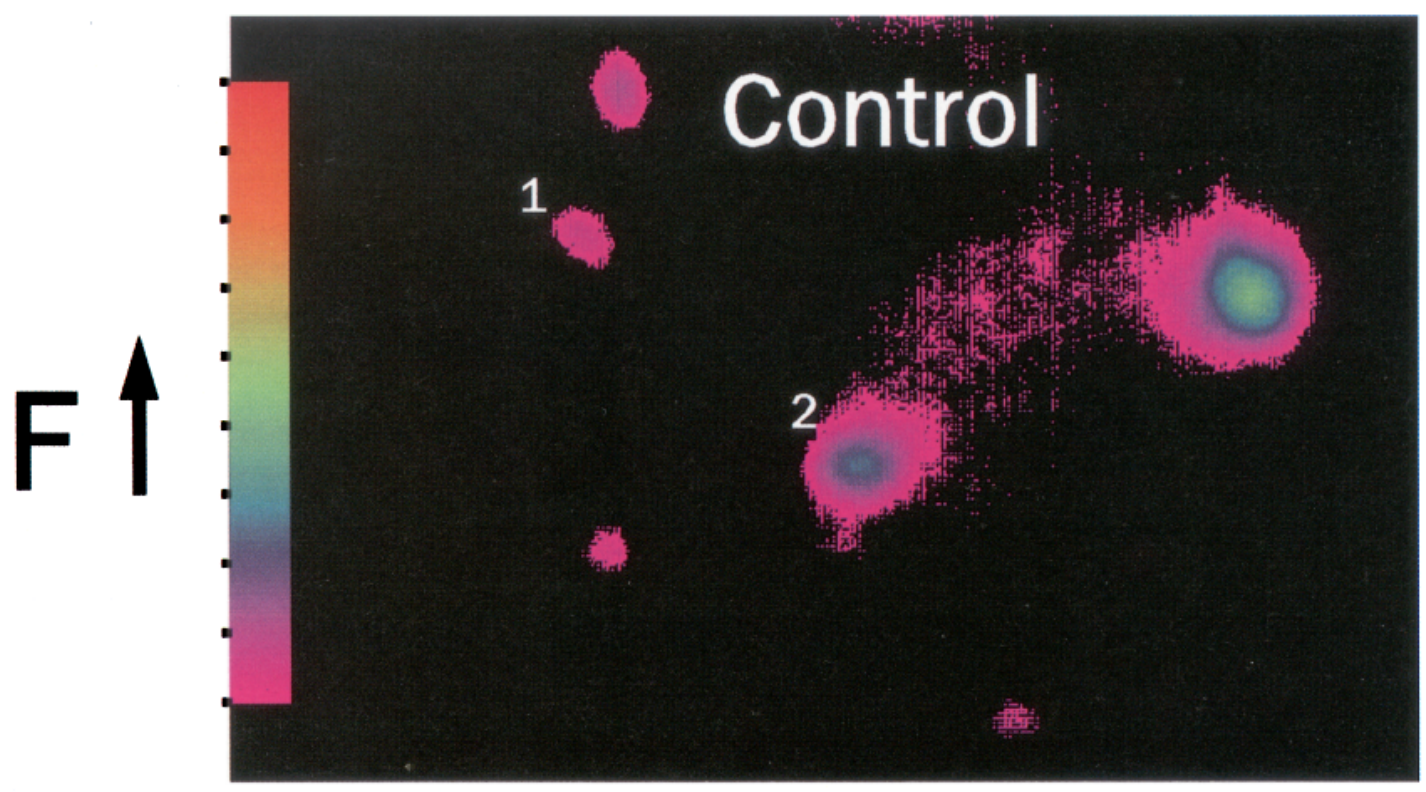

B

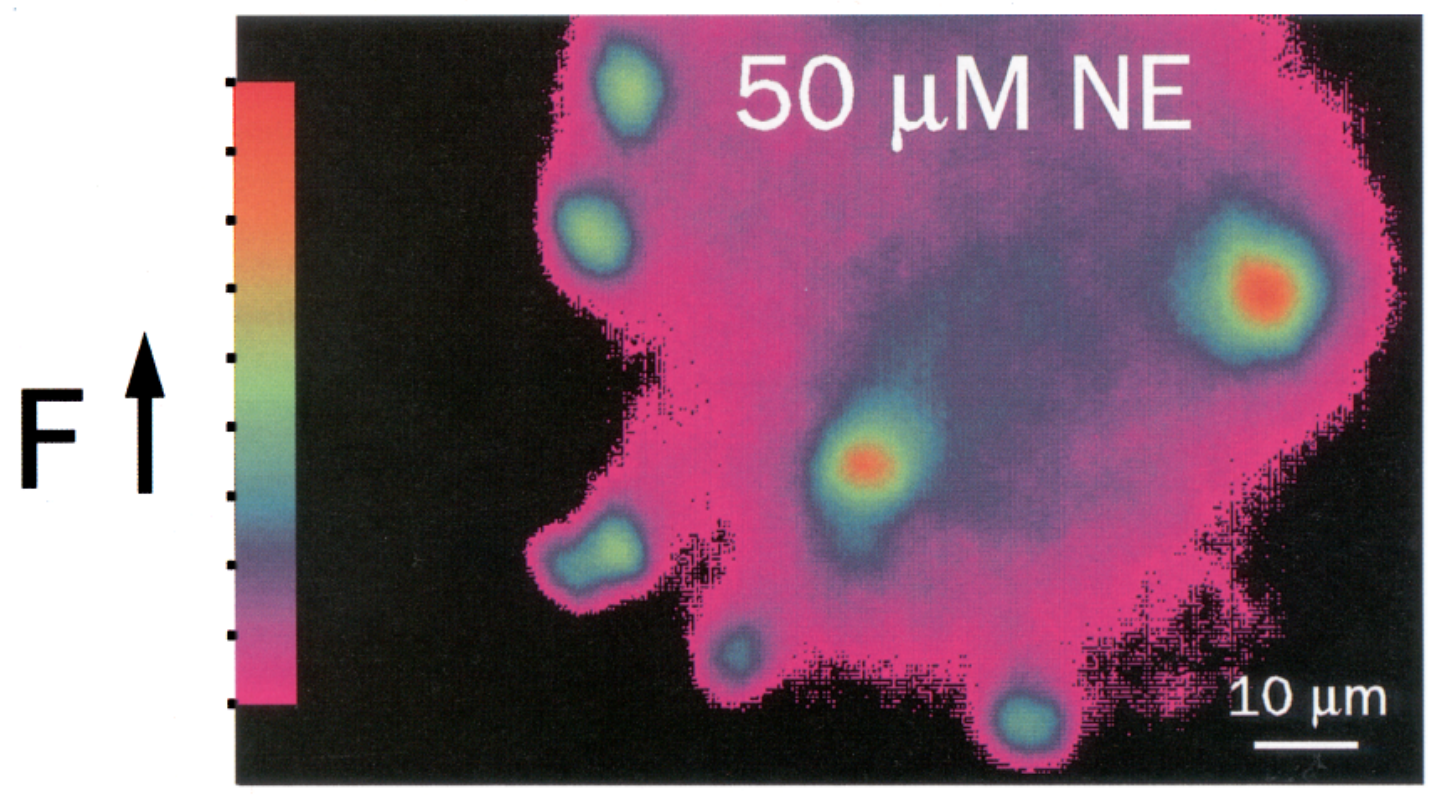

C

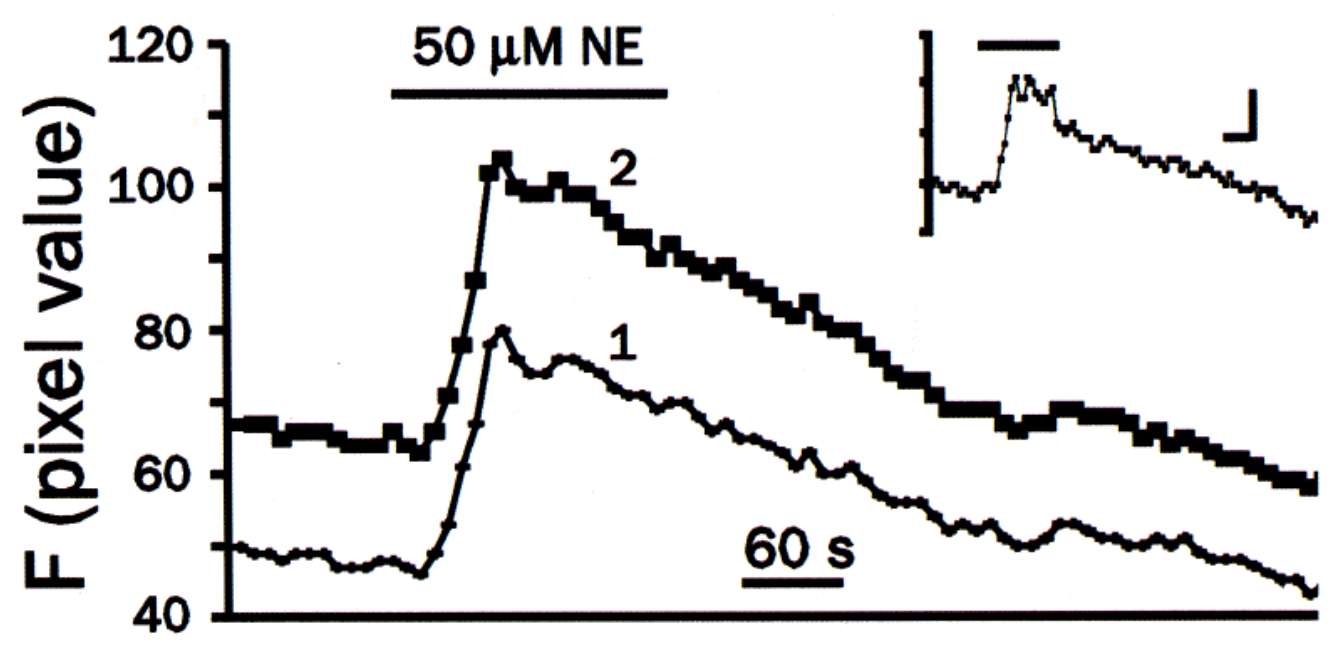



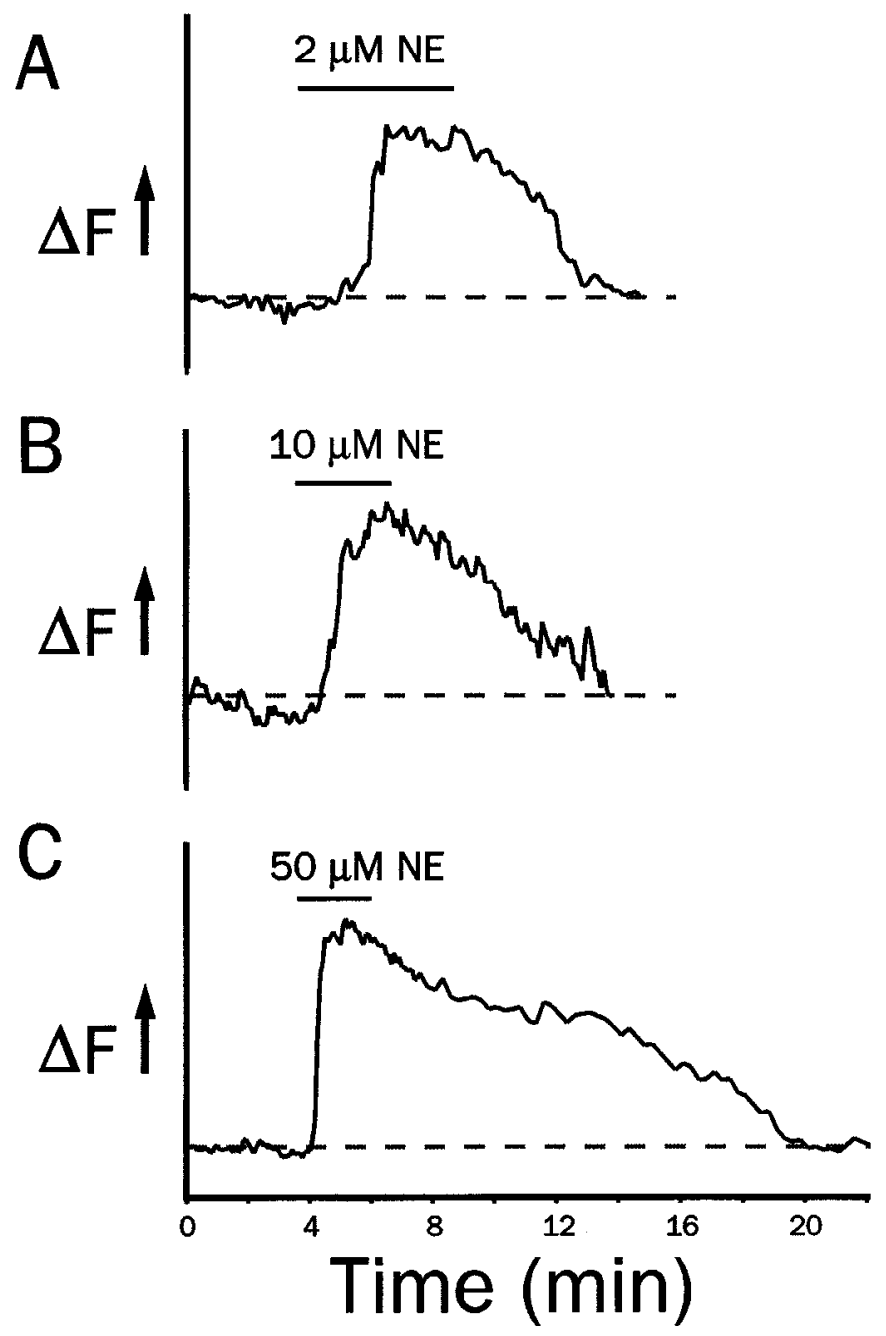

Figure 3. A broad range of NE concentrations $(2-50 \mu \mathrm{M})$ evoked $\left[\mathrm{Ca}^{2+}\right]_{i}$ increases with similar temporal characteristics. Each response from a separate slice.

a $\left[\mathrm{Ca}^{21}\right]_{i}$ increase (4 of 4 slices); moreover, robust $\mathrm{PE}$ responses were still observed in the presence of high concentrations $(2.5$ $5.0 \mu \mathrm{M}$ ) of the $\alpha_{2}$-antagonist yohimbine ( $n=3$ of 3 slices; Fig. $5 B$ ). These results indicate that $\alpha_{2}$-receptor stimulation did not contribute to the PE-evoked $\left[\mathrm{Ca}^{2+}\right]_{i}$ increase.

\section{Spontaneous $\left[\mathrm{Ca}^{2+}\right]_{\mathrm{i}}$ spiking in astrocytes}

In some slices $(\sim 10 \%)$, we observed spontaneous $\left[\mathrm{Ca}^{2+}\right]_{i}$ spiking activity, as has been reported in cultured astrocytes (Fatatis and Russell, 1992; T. H. Murphy et al., 1993) and P9-13 hippocampal astrocytes in situ (Porter and McCarthy, 1995). Like $\left[\mathrm{Ca}^{2+}\right]_{i}$ spikes elicited by $\mathrm{PE}$, these responses were generally independent in neighboring cells (Fig. 6). Because spontaneous $\left[\mathrm{Ca}^{2+}\right]_{i}$ spikes were absent in most slices, and because periods of spiking activity were sporadic even in spontaneously active slices, we could not study this form of $\left[\mathrm{Ca}^{2+}\right]_{i}$ signaling further.
Adrenergic-evoked release of $\left[\mathrm{Ca}^{2+}\right]$ from intracellular stores

PE-evoked responses were still observed following removal of extracellular $\left[\mathrm{Ca}^{2+}\right]_{o}$ (Fig. 7), and the response probability (8 of 9 slices or $89 \%, 27$ cells studied) was comparable to that observed in $2 \mathrm{mM}\left[\mathrm{Ca}^{2+}\right]_{o}$ (22 of 26 slices or $85 \%$ ), thus indicating that $\mathrm{PE}$ induced $\left[\mathrm{Ca}^{2+}\right]$ relcasc from internal stores. Responses usually consisted of both slow increases and spikes (duration $34.1 \pm 8.6 \mathrm{sec}$ ), while a minority ( 8 of 27 cells) showed only spiking. These PE-sensitive intracellular $\left[\mathrm{Ca}^{2+}\right]$ release stores were not $\left[\mathrm{Ca}^{2+}\right]_{i}$ sensitive, as caffeine (5 or $10 \mathrm{~mm}$ ) neither increased resting $\left[\mathrm{Ca}^{2+}\right]_{i}$ nor inhibited a subsequent response to PE $(n=4$, not shown).

\section{Adrenergic effects on membrane potential}

Depolarization increased the $\left[\mathrm{Ca}^{2+}\right]_{i}$ of astrocytes both within slices (Fig. 5) and in acutely isolated astrocytes (see Fig. 11). Since $\alpha_{1}$-receptor stimulation has been shown to depolarize astrocytes in culture, we tested for an $\alpha_{1}$-mediated depolarization which could contribute to the observed $\left[\mathrm{Ca}^{2+}\right]_{i}$ response (Bowman and Kimelberg, 1987; Enkvist et al., 1989). In intact hippocampal slices, PE either caused no change in $E_{m}$ ( 4 of 7 cells) or produced a hyperpolarization ( 3 of 7 cells; 5,15 , and $26 \mathrm{mV}$ ). The nature of this hyperpolarization was not studied further.

\section{Adrenergic $\left[\mathrm{Ca}^{2+}\right]_{\mathrm{i}}$ signals in acutely isolated astrocytes}

It is likely, based on pharmacology, that the receptors responsible for the $\left[\mathrm{Ca}^{2+}\right]_{i}$-mobilizing effects of PE and NE are of the $\alpha_{1}$ subtype. However, these data do not indicate whether these receptors are on astrocytes, or whether $\alpha_{1}$-agonists stimulate neuronal $\alpha_{1}$-receptors which in turn release (unidentified) messengers that mobilize astrocytic $\left[\mathrm{Ca}^{2+}\right]_{i}$. To determine the primary cellular locus of the PE effects, we measured the $\left[\mathrm{Ca}^{2+}\right]_{i}$ response of acutely isolated hippocampal astrocytes during bath application of NE or PE. Under these conditions, $\left[\mathrm{Ca}^{2+}\right]_{i}$ increases were still observed in response to $100 \mu \mathrm{M}$ PE or NE $(n=7)$ and PE-evoked increases were blocked by $50 \mathrm{nM}$ PRZ (Fig. $8 A$; $n=2$ ). The $\left[\mathrm{Ca}^{2+}\right]_{i}$ increases were restricted to the cell body and a few processes, as revealed by fura- 2 imaging experiments (Fig. 8A,B). These $\left[\mathrm{Ca}^{2+}\right]_{i}$ signals were, however, markedly different than those observed in slices. First, responses were more slowly developing (Fig. $8 B$ ), and $\left[\mathrm{Ca}^{2+}\right]_{i}$ measurements using indo-1 fluorescence did not reveal $\left[\mathrm{Ca}^{2+}\right]_{i}$ spiking (not shown). Second, while PE- or NE-induced $\left[\mathrm{Ca}^{2+}\right]_{i}$ responses were observed in all cells within responding hippocampal slices, $\left[\mathrm{Ca}^{2+}\right]_{i}$ increases were observed in only a small minority of acutely isolated cells $(<5 \%)$. Regardless, these results demonstrate that astrocytes possess an inherent ability to respond to $\alpha_{1}$-adrenergic receptor stimulation.

\section{The effect of glutamate and glutamate receptor agonists on astrocytic $\left[\mathrm{Ca}^{2+}\right]_{\mathrm{i}}$}

The response of hippocampal astrocytes to glutamate was also tested. Surprisingly, glutamate (0.75-2.0 mM) did not evoke an increase in $\left[\mathrm{Ca}^{2+}\right\rceil_{i}$ in either PE-responsive (Fig. $9 A ; n=7$ slices) or $\left[\mathrm{K}^{+}\right]_{o}$-responsive slices (50 $\mathrm{mM}\left[\mathrm{K}^{+}\right]_{o}, n=2$, not shown). Since hippocampal astrocytes and neurons express glutamate 
A Control
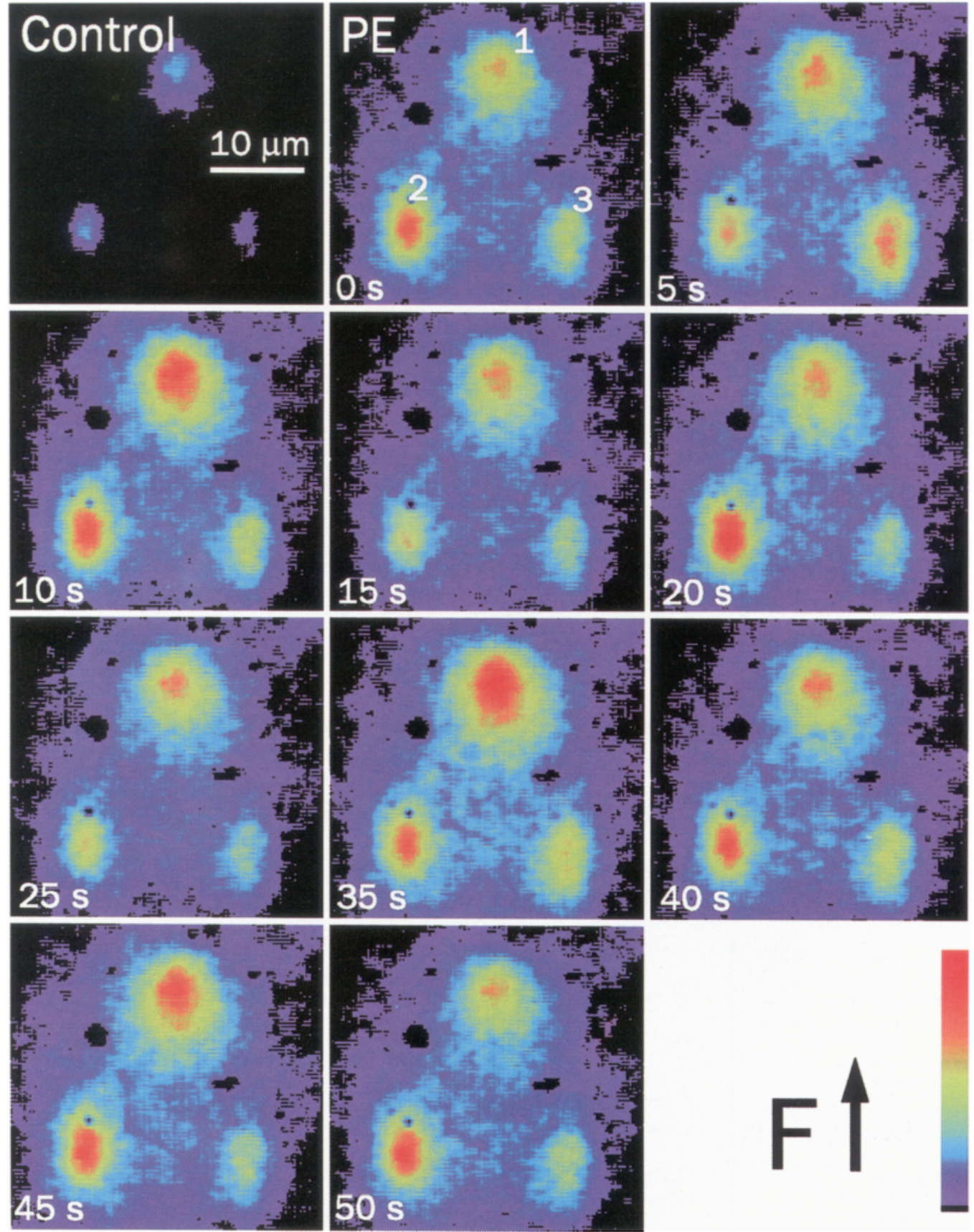

B

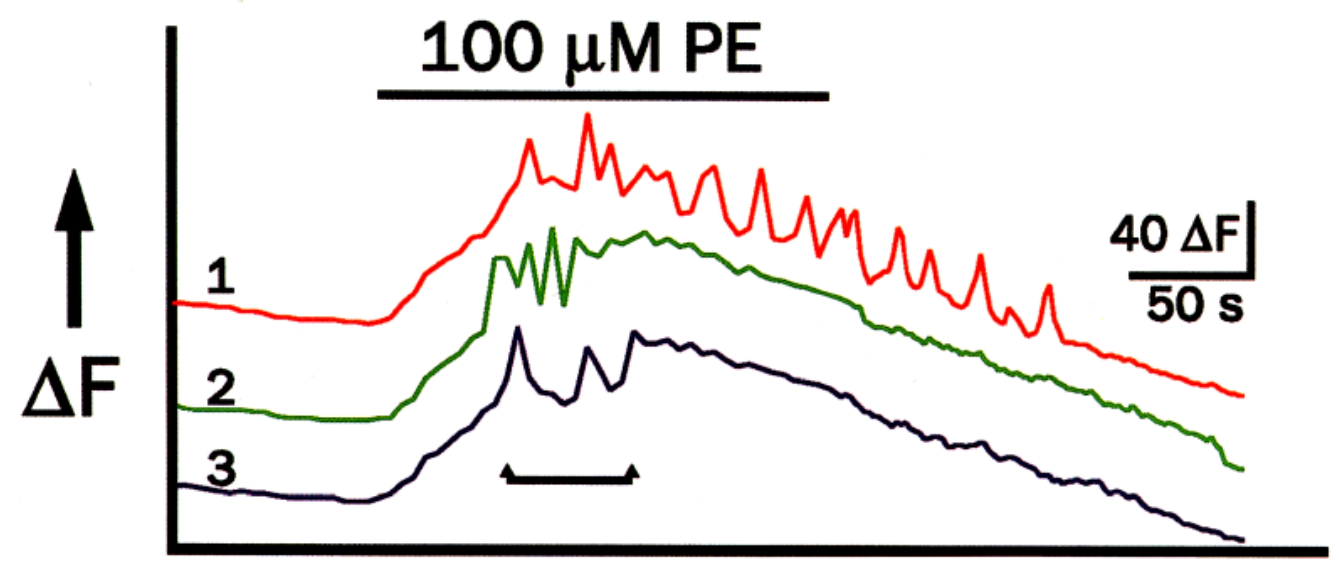




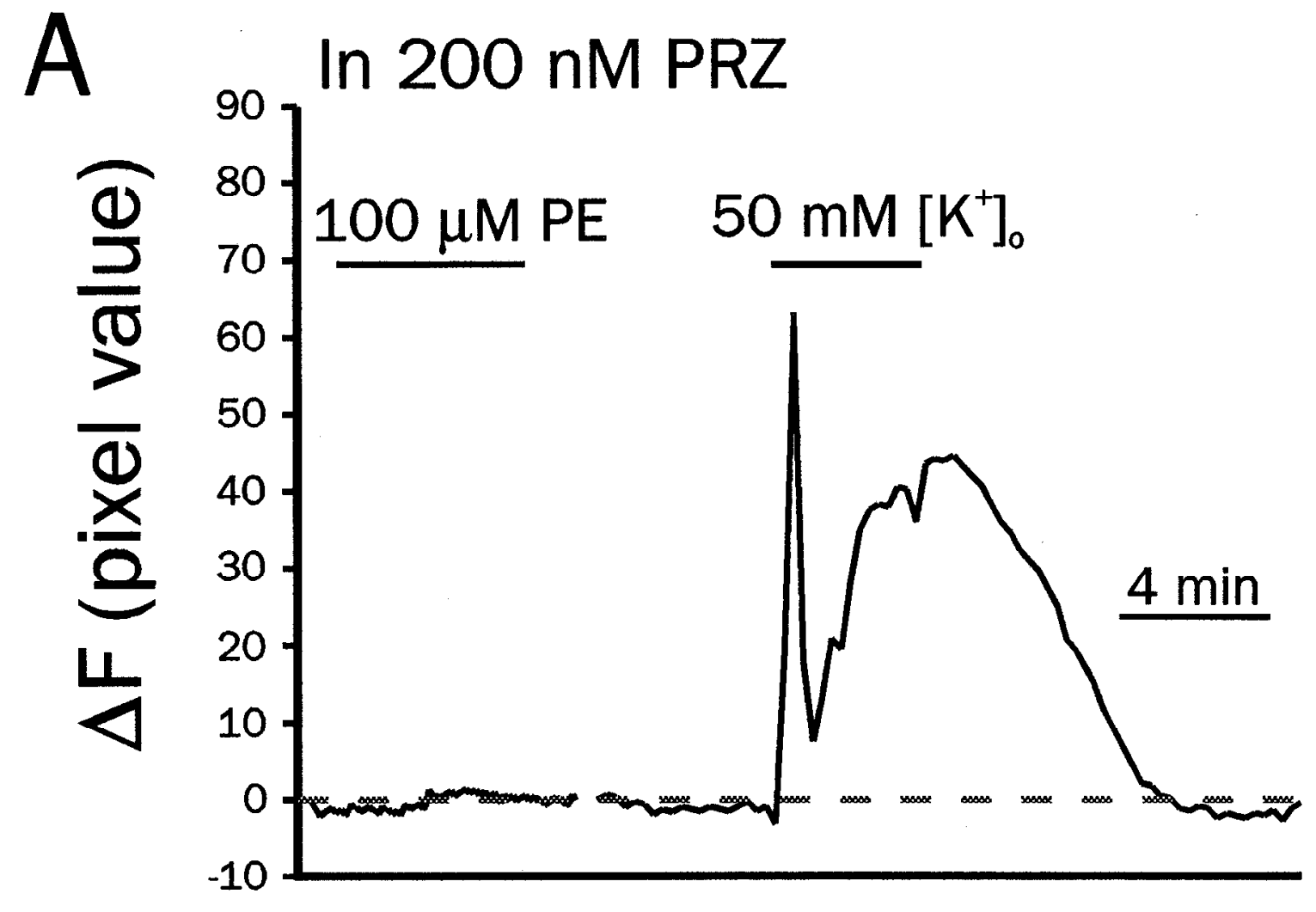

$\mathrm{B}$

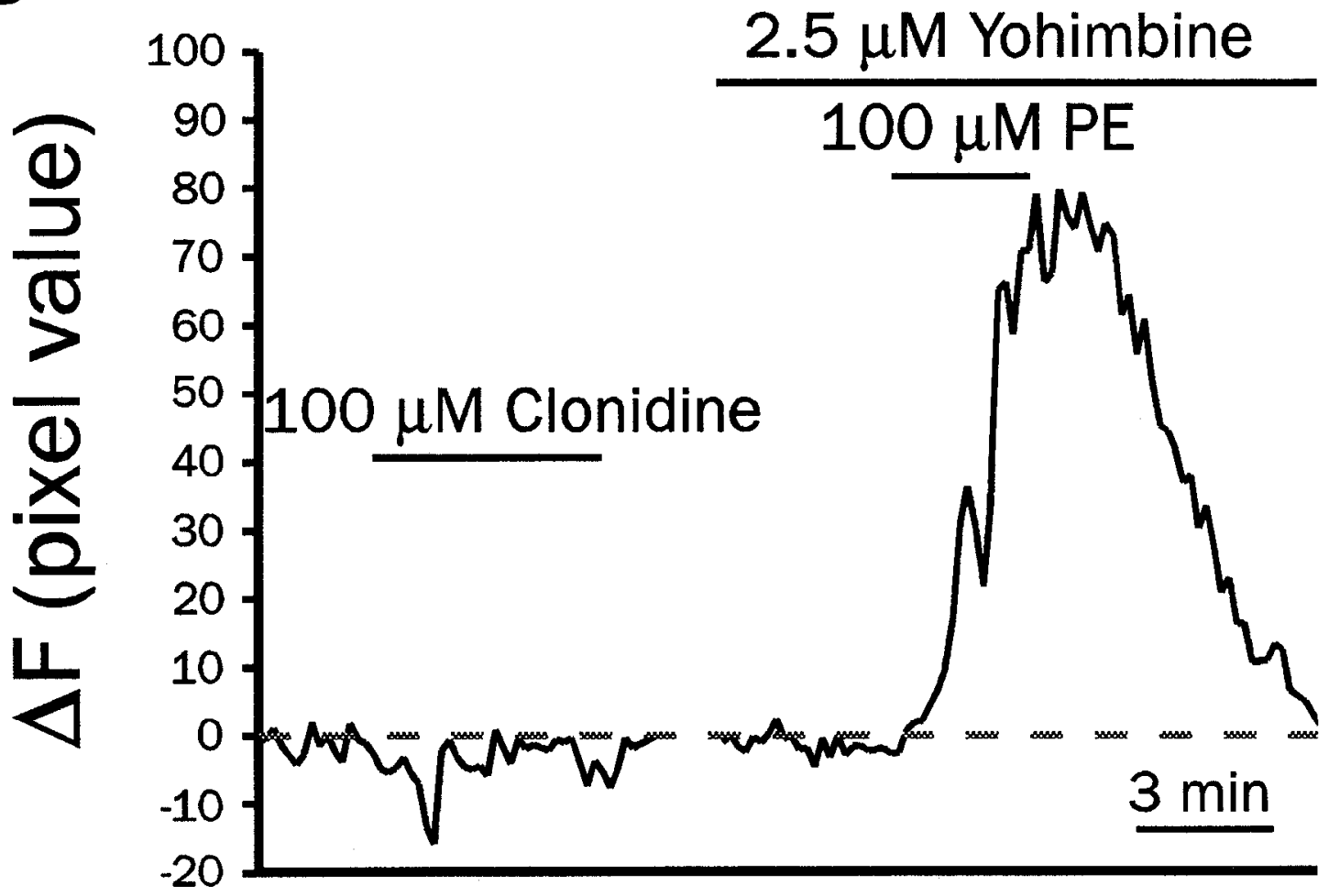

Figure 5. The PE-induced $\left[\mathrm{Ca}^{2+}\right]_{i}$ increase was mediated by $\alpha_{1}$-adrenergic receptors. $A$, Block of the PE effect by $200 \mathrm{nM}$ prazosin $(P R Z)$, an $\alpha_{1}$ adrenergic receptor antagonist. Subsequent application of $50 \mathrm{mM}\left[\mathrm{K}^{+}\right]_{o}$ evoked a reversible increase in astroglial $\left[\mathrm{Ca}^{2+}\right]_{i}, B$, The $\alpha_{2}$-agonist clonidine $(100 \mu \mathrm{M})$ did not evoke an increase in $\left[\mathrm{Ca}^{2+}\right]_{i}$, while PE-evoked $\left[\mathrm{Ca}^{2+}\right]_{i}$ increases were observed in the presence of the $\alpha_{2}$-antagonist yohimbine $(2.5 \mu \mathrm{M})$. Response in $A$ is a continuous trace from the same slice. Application of clonidine and PE in $B$ from separate slices. 


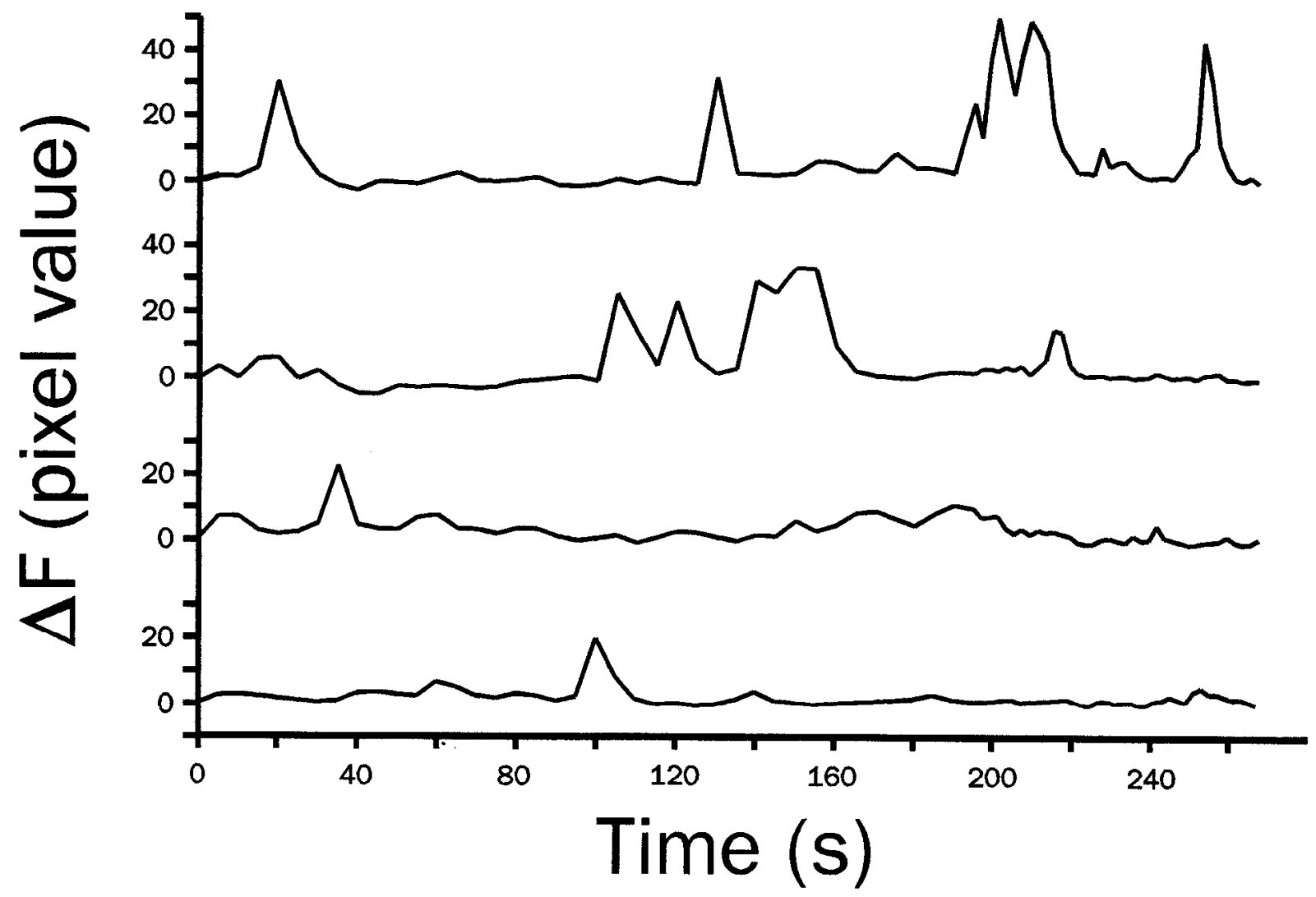

Figure 6. Spontaneous $\left[\mathrm{Ca}^{2+}\right]_{i}$ spikes in astrocytes. Four neighboring cells show rapid $\left[\mathrm{Ca}^{2+}\right]_{i}$ spiking in the absence of exogenous stimulation.

transporters that could reduce the extracellular glutamate concentration, we tested the effects of glutamate in the presence of the high-affinity competitive uptake inhibitor L-trans-pyrrollidine-2,4-dicarboxylic acid (PDC) (Fig. 9B). Glutamate (0.75-2.0 $\mathrm{mM})$ still did not elicit a $\left[\mathrm{Ca}^{2+}\right]_{i}$ increase in the presence of 300 $\mu \mathrm{M}$ PDC ( $n=5$ of 5 ). The metabotropic glutamate receptor agonist trans-( \pm )-1-amino-1,3-cyclopentanedicarboxylic acid (tACPD) (30 or $50 \mu \mathrm{M}$ ) did not elicit increases in $\left[\mathrm{Ca}^{2+}\right]_{i}$ (Fig. $10 A ; n=4)$. The ionotropic glutamate receptor agonist kainate $(200 \mu \mathrm{M}$ or $1 \mathrm{mM}$ ) also was ineffective in four of six slices (Fig.

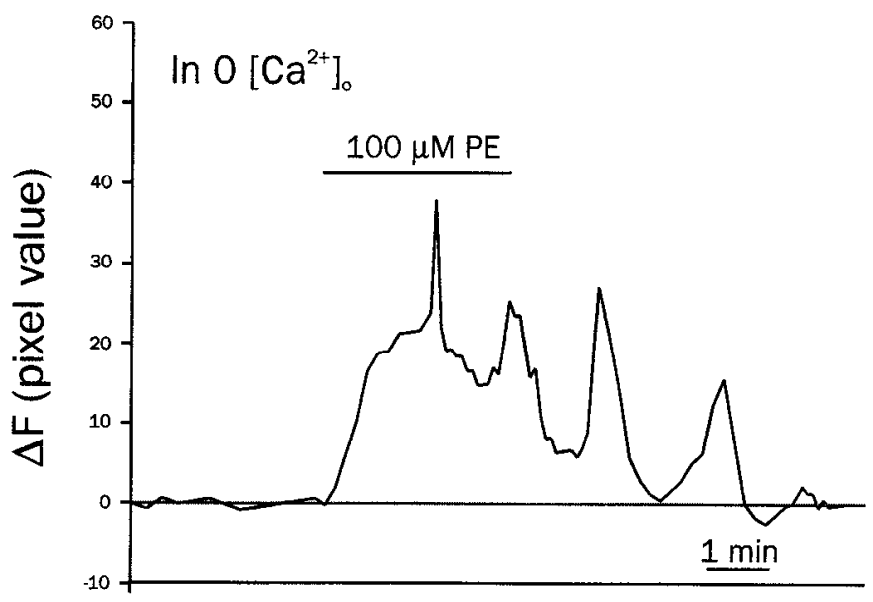

Figure 7. Increases in $\left[\mathrm{Ca}^{2+}\right]_{i}$ in response to $\mathrm{PE}$ were still observed after removal of extracellular calcium. Slice was preincubated in $\left[\mathrm{Ca}^{2+}\right]_{o}$-free aCSF for 20-25 min prior to PE application. Note that both slow responses and spiking persisted.
$10 B$ ). In fact, kainate usually induced a decrease in dye fluorescence, possibly due to cell swelling (Andrew and MacVicar, 1994). In two cases, kainate did induce a brief (1-2 min) $\left[\mathrm{Ca}^{2+}\right]_{i}$ increase which, unlike NE responses (Fig. $2 C$ ), was not reproduciblc upon a subsequent application. In all cases where Glu, kainate, or ACPD had no effect, subsequent application of PE $(50$ or $100 \mu \mathrm{M})$ or $50 \mathrm{mM}\left[\mathrm{K}^{+}\right]_{\text {o }}$ triggered a $\left[\mathrm{Ca}^{2+}\right]_{i}$ rise $(n=14$ of 14 slices). Finally, we tested the effect of glutamate on acutely isolated astrocytes where extracellular glutamate concentration could be controlled precisely. Similar to results in slices, glutamate $(1 \mathrm{mM})$ did not elicit a measurable $\left[\mathrm{Ca}^{2+}\right]_{i}$ increase in astrocyles loaded with indo-1 (Fig. 11;n=0 of 7), while $50 \mathrm{~mm}$ $\left[\mathrm{K}^{+}\right]_{o}$ induced a reversible increase $(n=7$ of 7$)$.

\section{Discussion}

Hippocampal astrocytes in situ responded directly to $\alpha_{1}$-adrenergic receptor stimulation with sustained $\left[\mathrm{Ca}^{2+}\right]_{i}$ increases and multiple $\left[\mathrm{Ca}^{2+}\right]_{i}$ spikes. In contrast, glutamate receptor stimulation, which induces $\left[\mathrm{Ca}^{2+}\right]_{i}$ spikes and propagating $\left[\mathrm{Ca}^{2+}\right]_{i}$ waves in cultured astrocytes, did not elicit $\left[\mathrm{Ca}^{2+}\right]_{i}$ increases in noncultured hippocampal slices. The most parsimonious conclusion from these results is that mature hippocampal astrocytes developing in vivo express $\alpha_{1}$-adrenergic receptors linked to $\left[\mathrm{Ca}^{2+}\right]_{i}$ mobilization, while glutamate receptors that mediate $\left[\mathrm{Ca}^{2+}\right]$ influx or internal release are downregulated.

\section{Specific loading of astroglia}

It is unlikely that cells other than astroglia were loaded with calcium orange. The passive electrophysiological responses to injected currents, the highly polarized resting membrane potentials, and the extensive dye coupling are exclusive to the astro- 
A
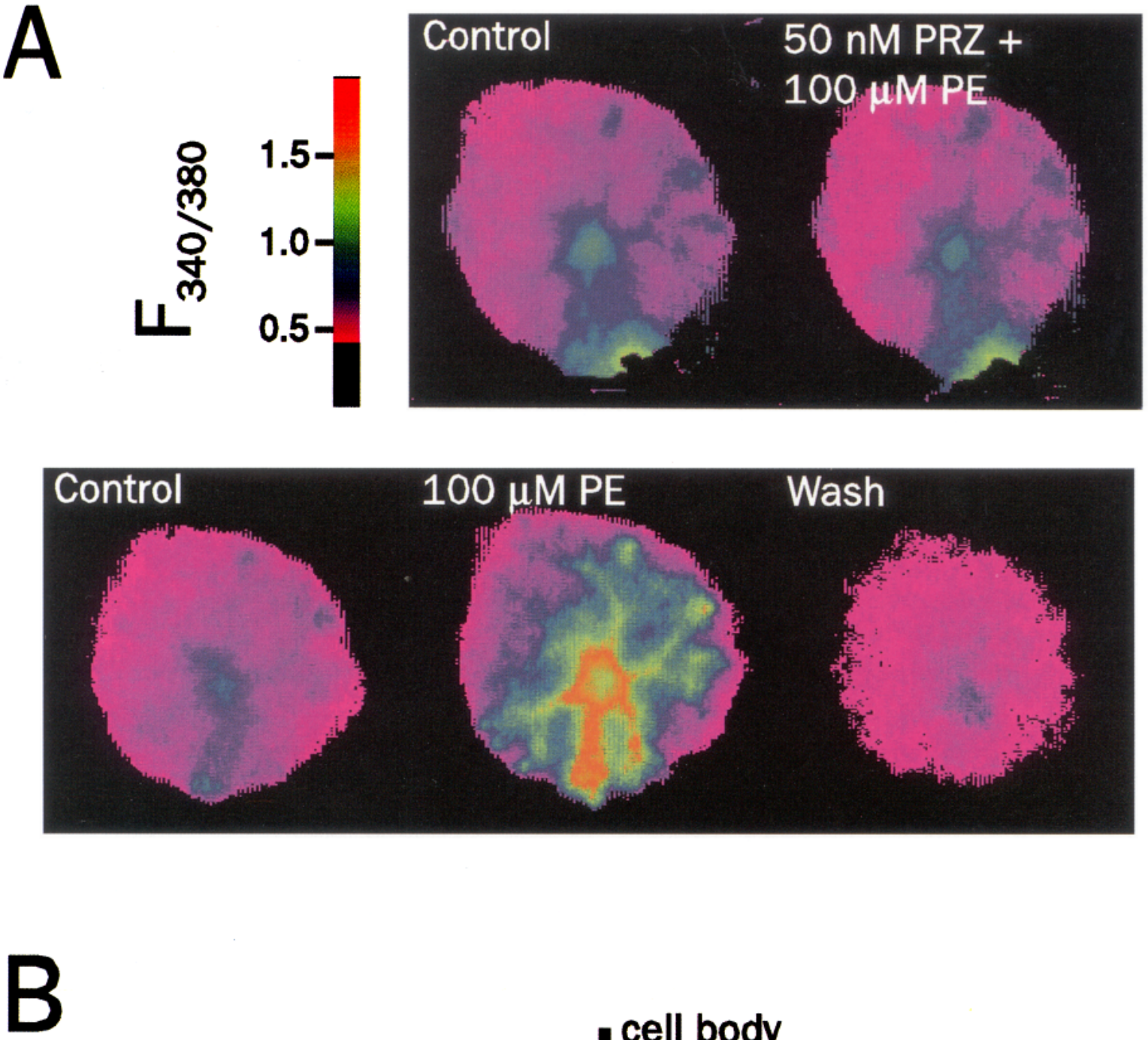

- cell body
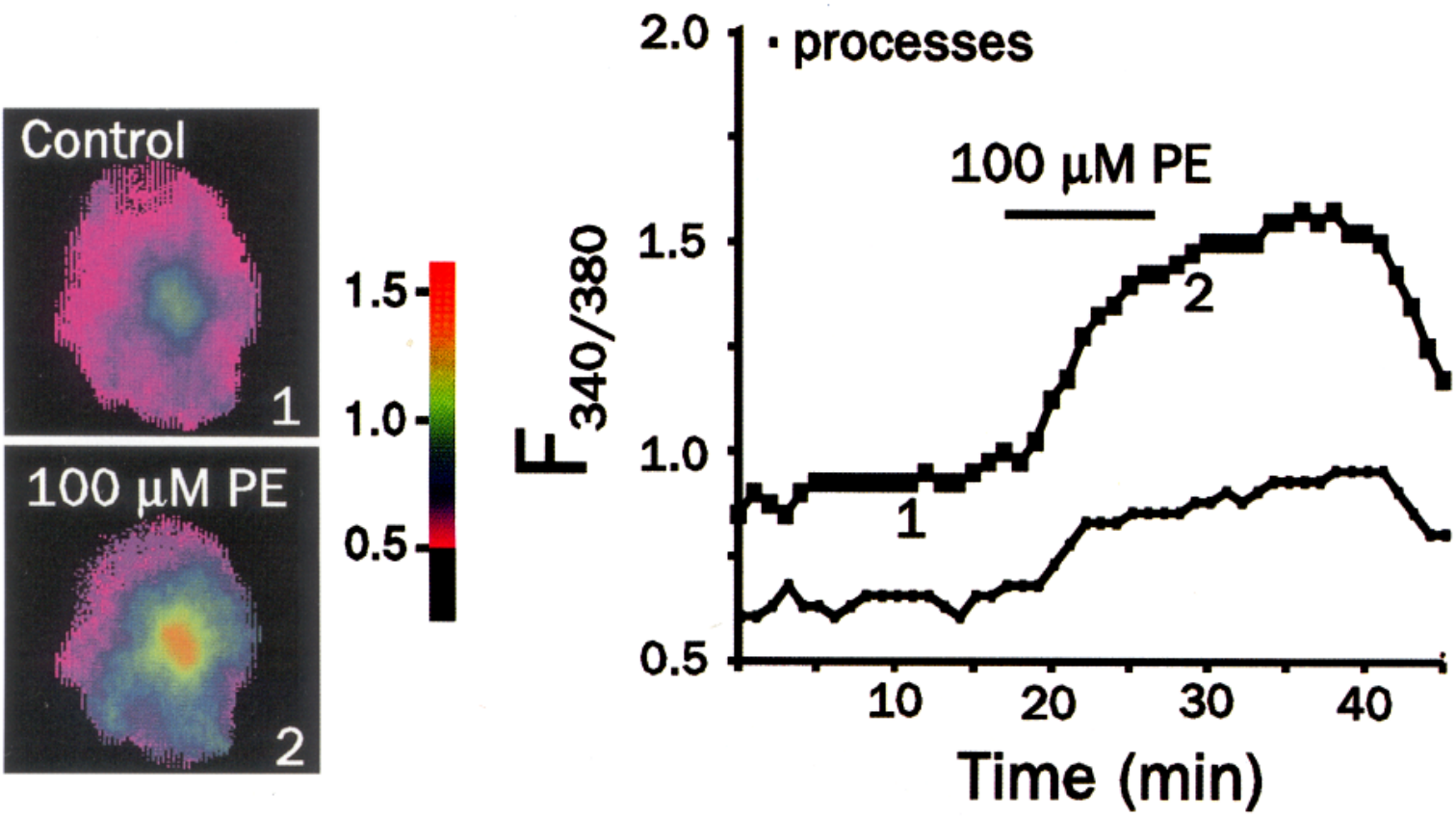

Figure 8. PE-evoked $\left[\mathrm{Ca}^{2+}\right]_{i}$ increases in fura-2-loaded acutely isolated astrocytes. $A$, Coapplication of $100 \mu \mathrm{M}$ PE and $50 \mathrm{nM}$ PRZ did not result in a $\left[\mathrm{Ca}^{2+}\right]_{i}$ increase (second panel). Subsequent addition of $100 \mu \mathrm{M}$ PE following washout of PRZ evoked a $\left[\mathrm{Ca}^{2+}\right]_{i}$ increase which was restricted mainly to the cell body and a few processes (fourth panel). B. From a different cell. The time course of the $\left[\mathrm{Ca}^{2+}\right]_{i}$ increase is plotted against time for the cell shown. PE elicited a prolonged and reversible $\left[\mathrm{Ca}^{2+}\right]_{i}$ increase. 


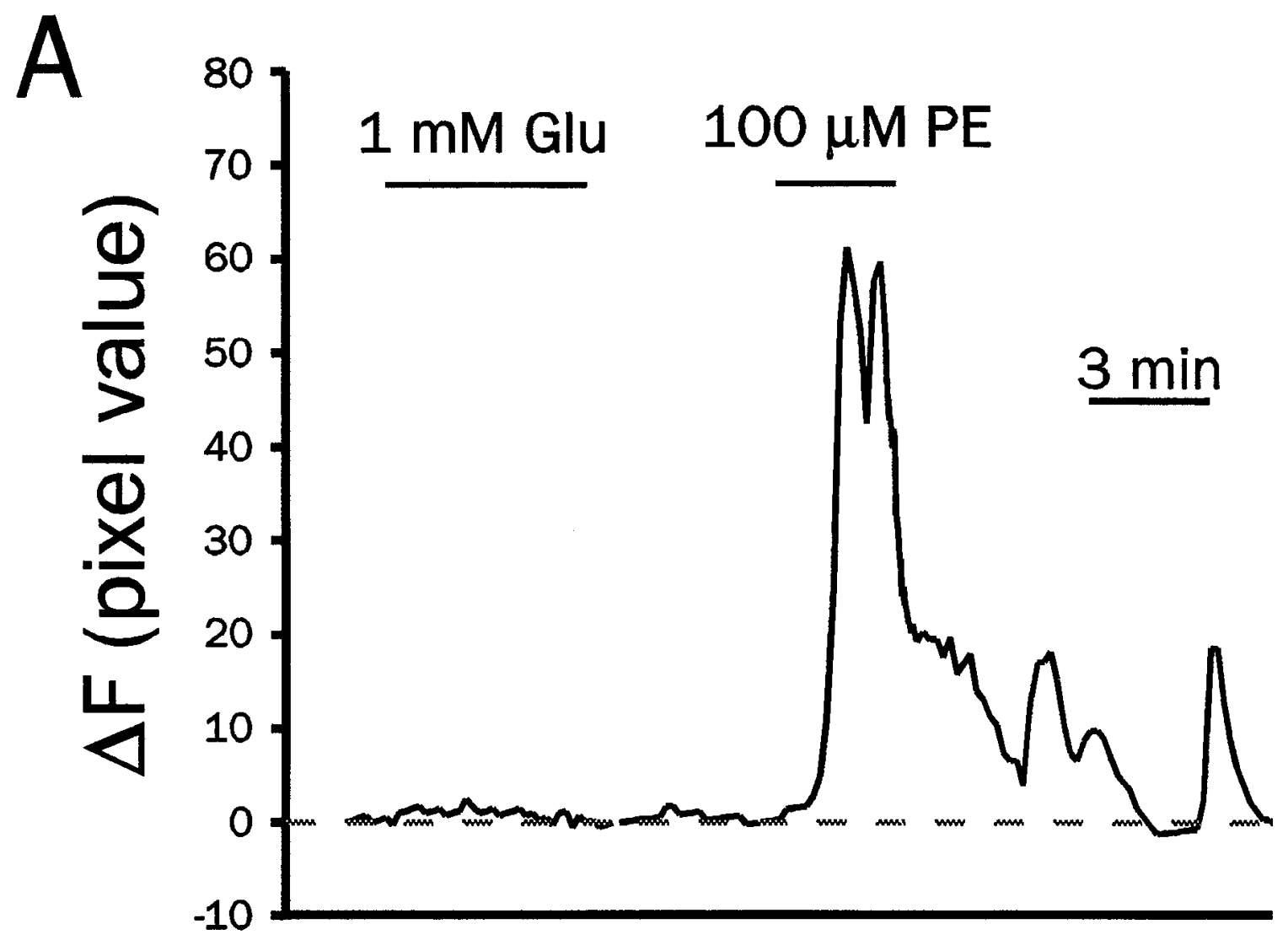

$D$

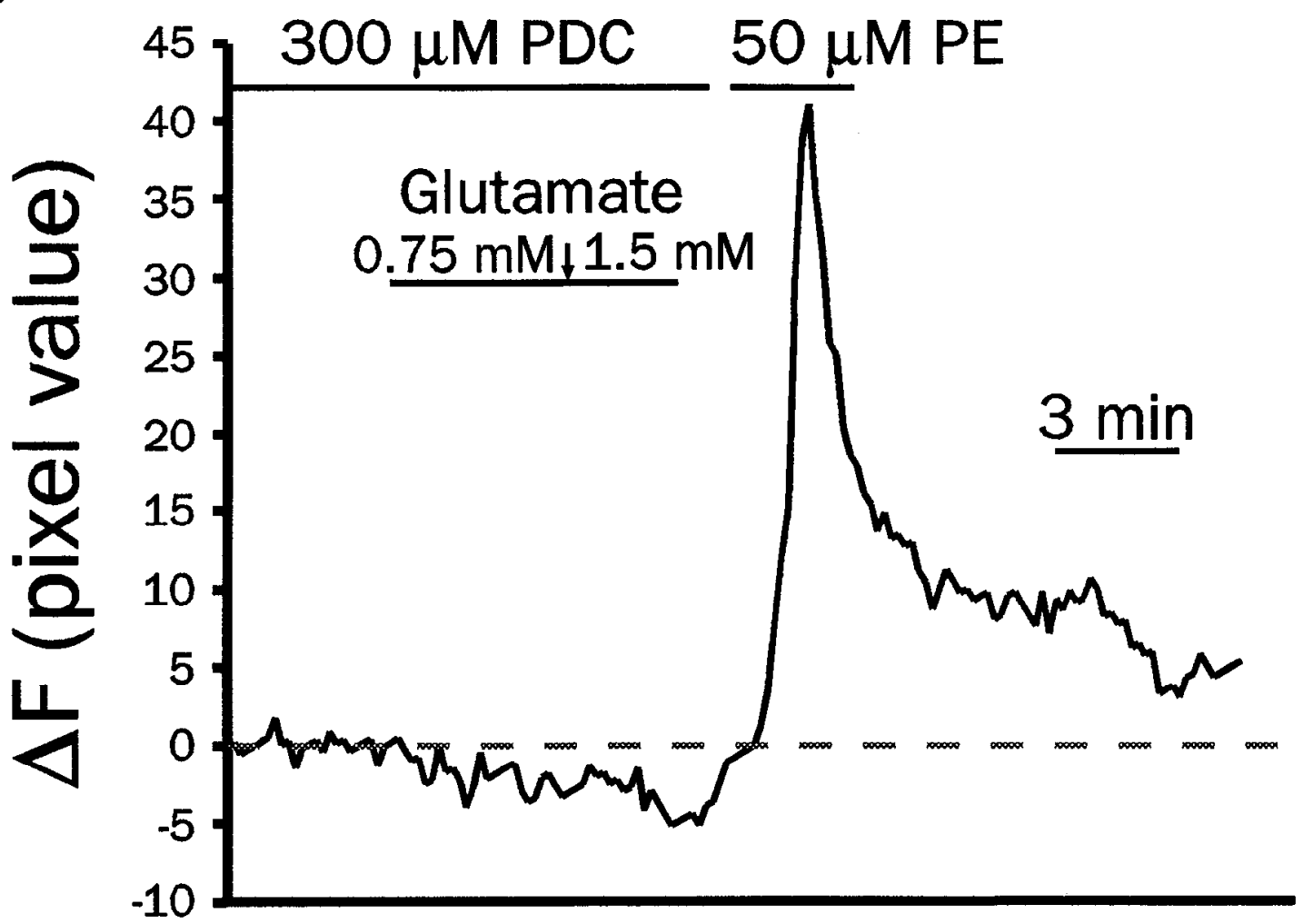

Figure 9. Glutamate $(G l u)$ did not evoke [ $\left.\mathrm{Ca}^{2+}\right]_{i}$ elevations in astrocytes, either alone $(A)$ or in the presence of a glutamate uptake blocker $(P D C$; $B)$. A, Comparison of a $5 \mathrm{~min}$ application of glutamate $(1 \mathrm{mM})$ with $100 \mu \mathrm{M}$ PE $(3 \mathrm{~min})$. Glutamate did not evoke a detectable response in a cell with a robust response to PE. $B$, Glutamate did not increase $\left[\mathrm{Ca}^{2+}\right]_{i}$ in the presence of a glutamate uptakc inhibitor. PDC (300 $\left.\mu M\right)$, superfused before and during glutamate $(0.75$ and $1.50 \mathrm{mM})$ application. Following washout, $50 \mu \mathrm{MPE}$ induced a $\left[\mathrm{Ca}^{2+}\right]_{i}$ increase. 


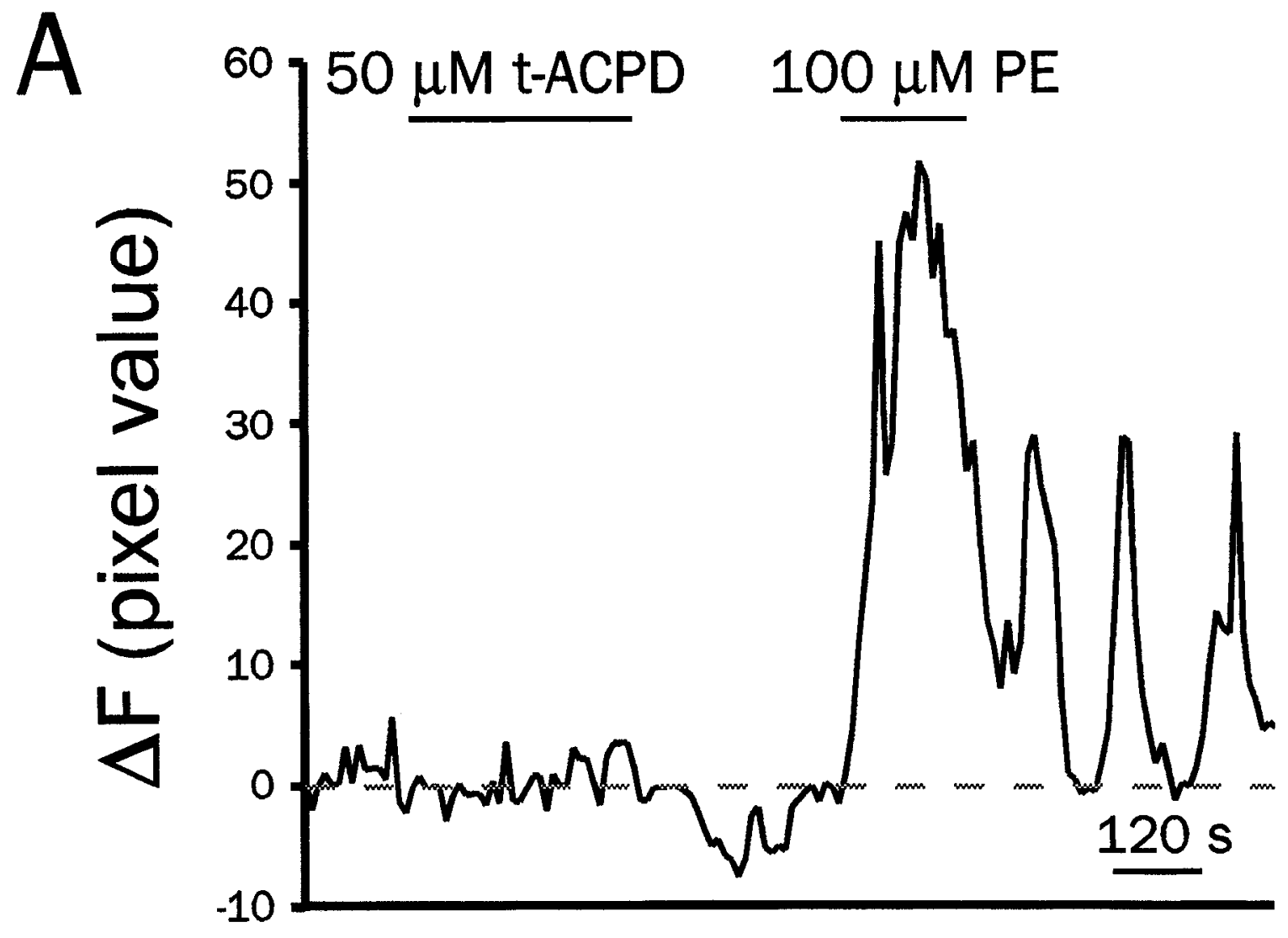

B

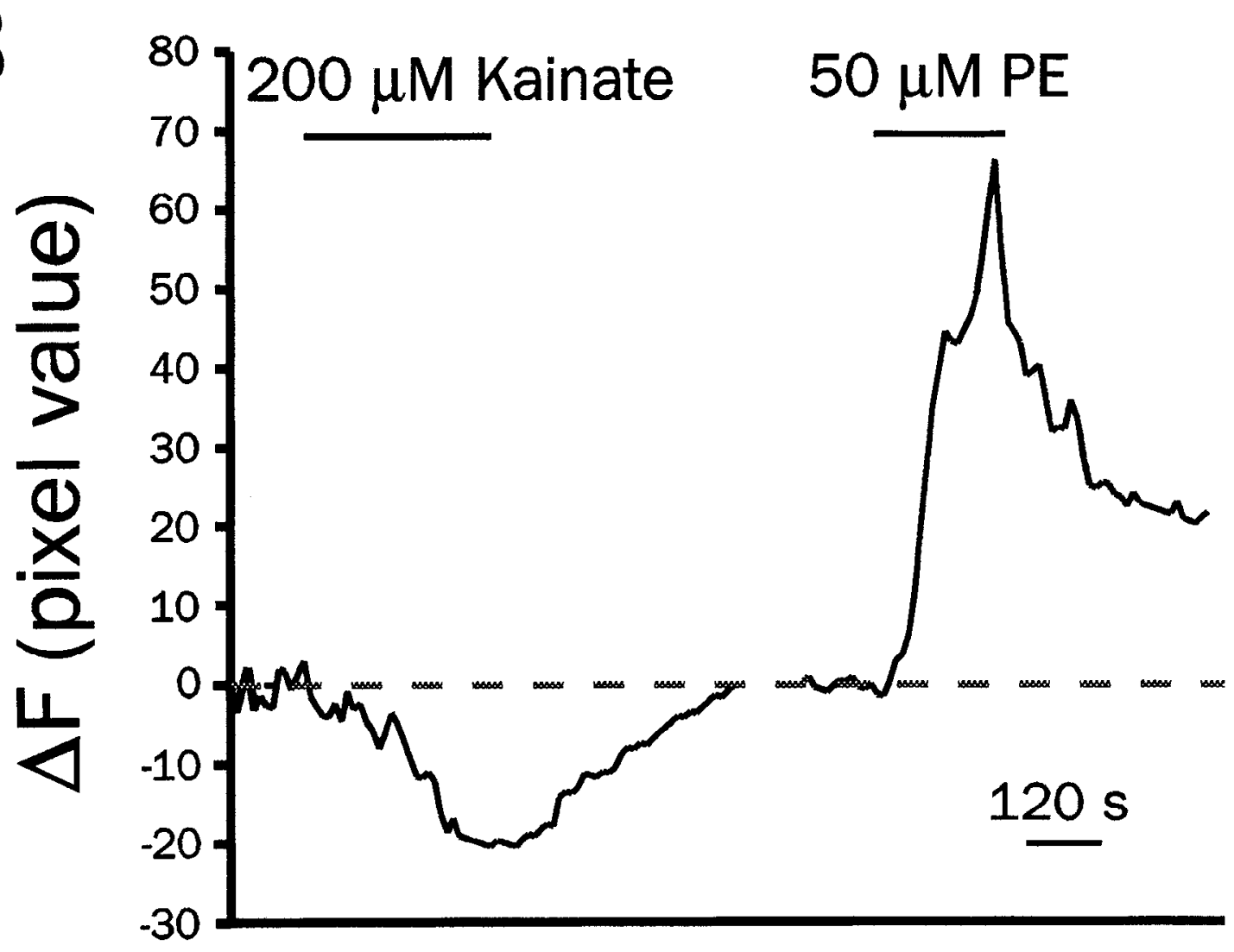

Figure 10. Agonists for metabotropic and ionotropic glutamate receptors did not increase astrocytic $\left[\mathrm{Ca}^{2+}\right]_{i} . A$, The metabotropic agonist $\mathrm{t}$-ACPD $(50 \mu \mathrm{M})$ did not elicit a $\left[\mathrm{Ca}^{2+}\right]_{i}$ increase in a PE-responsive astrocyte. $B$, The ionotropic agonist kainate $(200 \mu \mathrm{M})$ did not evoke a $\left[\mathrm{Ca}^{2+}\right]_{i}$ increase in a PE-responsive astrocyte; rather, an apparent $\left[\mathrm{Ca}^{2+}\right]_{i}$ decrease was observed. 


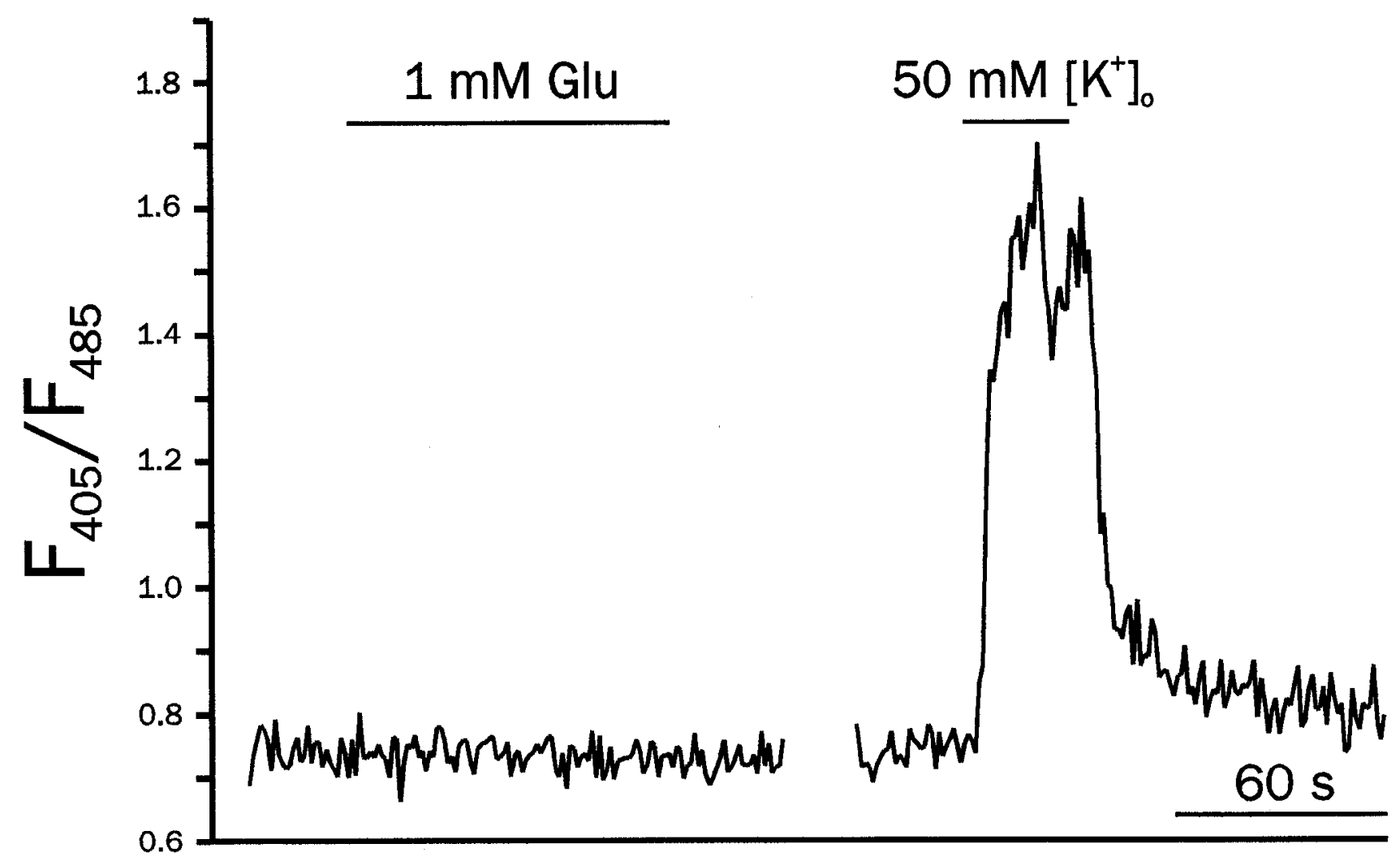

Figure 11. Glutamate did not increase the $\left[\mathrm{Ca}^{2+}\right]_{i}$ of acutely isolated astrocytes. A $90 \mathrm{sec}$ application of glutamate caused no $\left[\mathrm{Ca}{ }^{2+}\right]_{i}$ increase, but a subsequent application of $50 \mathrm{~mm}\left[\mathrm{~K}^{+}\right]_{o}$ for $30 \mathrm{sec}$ evoked a large, reversible $\left[\mathrm{Ca}^{2+}\right]_{i}$ increase.

cytic phenotype (Takato and Goldring, 1979; Gutnick et al., 1981; Connors et al., 1984; Burnard et al., 1990; Mudrick-Donnon et al., 1993; Sontheimer and Waxman, 1993; Koneintzko and Muller, 1994). Input resistances were higher than reported previously for hippocampal astrocytes (Burnard et al., 1990), but this likely resulted from the use of low $\mathrm{K}$-acetate concentrations in the microelectrode, which optimized dye loading over electrophysiological recording. Nonetheless, electrophysiological responses which differentiate astroglia from neurons (stimulusevoked action potentials and impalement spiking) could be measured. It is also unlikely that dye would pass from astroglia into another cell type. Dye coupling between astrocytes and neurons or microglia has not been demonstrated in situ. On the other hand, dye coupling between astrocytes and oligodendrocytes has been observed in rabbit retina (Robinson et al., 1993). While putative oligodendrocytes were occasionally injected, these morphologically distinct cells were never observed in association with clusters of the smaller dye-coupled cells that responded to $\mathrm{NE}, \mathrm{PE}$, and $50 \mathrm{mM}\left[\mathrm{K}^{+}\right]_{\text {. }}$.

\section{Fluorometric $\left[\mathrm{Ca}^{2+}\right]_{\mathrm{i}}$ measurements using calcium orange}

We employed the rhodamine-based dye calcium orange exclusively in our hippocampal slices studies because there is little spectral overlap between peak dye emission wavelength $(\approx 580$ $\mathrm{nm})$ and tissue autofluorescence $(380-500 \mathrm{~nm})$. Like all BAPTA-based dyes, calcium orange is sensitive to intracellular $\mathrm{pH}$ (Eberhard and Erne, 1991) and PE has been shown to evoke slow cytoplasmic alkalinizations in cardiac myocytes by a protein kinase $\mathrm{C}$ (PKC)-mediated increase in $\mathrm{Na}-\mathrm{H}$ exchange (Iwakura et al., 1990). Those $\mathrm{pH}$ changes were, however, more slowly developing than the $\left[\mathrm{Ca}^{2+}\right]_{i}$ increases observed here. Moreover, the $K_{d}$ of calcium orange changes only $8.7 \%$ from $\mathrm{pH} 7.2$ to $\mathrm{pH}$ 8.0 (Eberhard and Erne, 1991), while PE-evoked alkalinizations in myocytes were only $0.01-0.10 \mathrm{pH}$ units. Thus, significant interference from intracellular $\mathrm{pH}$ changes is unlikely.

Pharmacological characterization of the astrocyte adrenergic response in hippocampal slices

Adrenergic responses were mediated primarily by activation of the $\alpha_{1}$ subtype of adrenergic receptor since only the $\alpha_{1}$-agonist $\mathrm{PE}$, and not the $\alpha_{2}$-agonist clonidine, elicited $\left[\mathrm{Ca}^{2+}\right]_{i}$ responses. The bath concentrations required for large PE effects (50-100 $\mu \mathrm{M})$ were somewhat higher than required in culture, but this was likely due to reduced agonist concentrations around dye-loaded astrocytes. The tissue-bath partition coefficient of PE is not known, but carbachol, a cation of approximately equal molecular weight, reached only $10 \%$ of bath concentration within hippocampal slices after $5 \mathrm{~min}$ superfusion (Muller et al., 1988). The PE-induced $\left[\mathrm{Ca}^{2+}\right]_{i}$ signal was also blocked by $50-200 \mathrm{nM}$ prazosin. At these (bath) concentrations, PRZ is a specific $\alpha_{1}$-antagonist; significant blockade of $\alpha_{2}$-agonist effects (Brown et al., 1980) or $\alpha_{2}$-receptor binding (Minneman and Johnson, 1984) is observed only at PRZ concentration approaching $10 \mu \mathrm{M}$. While lipophilic compounds like PRZ may accumulate to many times bath concentration and block $\alpha_{2}$-receptors (Lullmann et al., 1979), we found no evidence for $\alpha_{2}$-mediated $\left[\mathrm{Ca}^{2+}\right]_{i}$ responses in the presence of the $\alpha_{2}$-agonist clonidine. Moreover, PE responses were still observed in the presence of 2.5-5.0 $\mu \mathrm{M}$ of the $\alpha_{2}$-antagonist yohimbine.

\section{Intracellular $\mathrm{Ca}^{2+}$ stores in astrocytes}

Removal of external calcium did not abolish PE-evoked $\left[\mathrm{Ca}^{2+}\right]_{i}$ increases, indicating that $\mathrm{PE}$ released $\left[\mathrm{Ca}^{2+}\right]$ from internal stores. 
These stores are likely to be $\mathrm{IP}_{3}$ sensitive, rather than $\left[\mathrm{Ca}^{2+}\right]_{i}$ sensitive, since caffeine did not mobilize $\left[\mathrm{Ca}^{2+}\right]_{i}$ or inhibit a response to subsequent PE application. These data are consistent with previous results in both cultured astrocytes (Salter and Hicks, 1994) and acutely isolated astrocytes (Duffy and MacVicar, 1994) that showed no significant caffeine-evoked $\left[\mathrm{Ca}^{2+}\right]_{i}$ increases.

\section{Depolarization and astrocytic $\left[\mathrm{Ca}^{2+}\right]$}

Depolarization of astrocytes by elevating the extracellular $\left[\mathrm{K}^{+}\right]_{o}$ to $50 \mathrm{mM}$ increased $\left[\mathrm{Ca}^{2+}\right]_{i}$, presumably by activating voltagedependent Ca channels (MacVicar, 1984; Barres et al., 1990; Duffy and MacVicar, 1994). Similarly, rat astrocytes from P913 hippocampus also show $\left[\mathrm{K}^{+}\right]_{0}$-dependent $\left[\mathrm{Ca}^{2+}\right]_{i}$ increases (Porter and McCarthy, 1995). In contrast, the "complex" glial cells from young (P9-12) mouse showed no voltage-dependent $\left[\mathrm{Ca}^{2+}\right]_{i}$ signaling (Jabs et al., 1994), suggesting that Ca channel expression is heterogeneous in astroglial subtypes. Our results indicate that in mature gray matter, stimuli associated with large elevations in $\left[\mathrm{K}^{+}\right]_{o}$ and astrocytic depolarization (e.g., spreading depression and anoxia) result in $\left[\mathrm{Ca}^{2+}\right]$ influx into astrocytes (Duffy and MacVicar, unpublished observations).

It was previously reported that $\alpha_{1}$ stimulation evoked large depolarizations in cultured astrocytes (Bowman and Kimelberg, 1987; Akerman et al., 1988). This result suggested that PE or NE could increase $\left[\mathrm{Ca}^{2+}\right]_{i}$ of astrocytes within hippocampal slices by opening voltage-gated $\mathrm{Ca}$ channels. In the present experiments, however, PE did not depolarize astroglia. In some cases, a distinct hyperpolarization was observed. The mechanism underlying this effect was not determined, although PE-evoked $\left[\mathrm{Ca}^{2+}\right]_{i}$ signals could activate $\left[\mathrm{Ca}^{2+}\right]_{i}$-dependent $\mathrm{K}$ channels (Quandt and MacVicar 1986).

Adrenergic $\left[\mathrm{Ca}^{2+}\right]_{\mathrm{i}}$ responses in astrocytes in brain slices versus cultured astrocytes

$\alpha_{1}$-Adrenergic $\left[\mathrm{Ca}^{2+}\right]_{i}$ responses wcre also obscrved in acutely isolated hippocampal astrocytes, indicating that the PE-induced response resulted, at least in part, from stimulation of $\alpha_{1}$-receptors located on astrocytic membranes. These results do not eliminate a contribution from other sources, for example, release of diffusible second messengers from neuronal $\alpha_{1}$-receptor stimulation, as $\mathrm{PE}\left[\mathrm{Ca}^{2+}\right]_{i}$ signals in acutely isolated astrocytes were slow relative to those in slices and no sign of rapid spiking was observed. Alternatively, it is possible that an intact astroglial network (syncytium) is necessary for the emergence of all the response characteristics observed in intact slices. We also observed a great disparity in response probabilities between slices (roughly $85-90 \%$ of all cells studied) compared to acutely isolated cells $(\approx 5 \%)$. This could be interpreted as evidence that astrocytic adrenergic receptors are found in only a small subset of astrocytes, as has been reported in culture (Dave et al., 1991), and that gap junctions between astrocytes act to propagate $\left[\mathrm{Ca}^{2+}\right]_{i}$ changes to surrounding cells. As well, the isolation procedure could have inactivated $\alpha_{1}$-receptors (proteolysis by papain) or altered the state of internal $\left[\mathrm{Ca}^{2+}\right]$ stores.

\section{Absence of a glutamate-evoked $\left[\mathrm{Ca}^{2+}\right]_{\mathrm{i}}$ response}

Neither glutamate nor the glutamate receptor agonist t-ACPD cvoked measurable $\left[\mathrm{Ca}^{2+}\right]_{i}$ increases in astrocytes within hippocampal slices. This result is surprising in light of the voluminous literature describing Glu-evoked $\left[\mathrm{Ca}^{2+}\right]_{i}$ signals in cultured hippocampal astrocytes (Cornell-Bell et al., 1990; Glaum et al., 1990), hippocampal astrocytes in organotypic culture (Dani et al., 1992), or hippocampal glia in situ (Jabs et al., 1994; Steinhauser et al., 1994; Porter and McCarthy, 1995). It is unlikely that this negative result merely reflects a limited access of bath-applied glutamate to astrocyte glutamate receptors. While endogenous glutamate transporters may reduce the interstitial glutamate concentration considerably below bath concentration (Garthwaite, 1985), glutamate was also without effect in the presence of saturating levels of the high-affinity competitive inhibitor of glutamate uptake, PDC (Sarantis et al., 1993). High concentrations of kainate did evoke brief increases in $\left[\mathrm{Ca}^{2+}\right]_{i}$ in two instances, but these responses were not repeatable, and kainate may initiatc other processes, such as spreading depression and transmitter release, both of which could also cause a $\left[\mathrm{Ca}^{2+}\right]_{i}$ response in astrocytes. Moreover, no glutamate response was observed in acutely isolated astrocytes where both uptake and indirect $\left[\mathrm{Ca}^{2+}\right]_{i}$ mobilizing mechanisms would be eliminated.

It appears, therefore, that astrocytes within P21-42 rat hippocampal slices do not generally express glutamate receptors linked to $\left[\mathrm{Ca}^{2+}\right]_{i}$ mobilization, or at least such expression is significantly downregulated relative to astrocytes in primary culture or younger brain slices. An interesting possibility is that expression of astrocytic $\left[\mathrm{Ca}^{2+}\right]_{i}$-mobilizing glutamate receptors is under developmental control. The state of differentiation is an important determinant of both ionic channel phenotype (MacVicar and Tse, 1988; Barres et al., 1989, 1990) and the patterns of receptor expression (Shao et al., 1993). For example, the present results show that fully differentiated astrocytes exhibit voltage-dependent $\left[\mathrm{Ca}^{2+}\right]_{i}$ signals, while such expression was absent in immature hippocampus (Jabs et al., 1994). It is possible that glutamate acts to arrest proliferation (Condorelli et al., 1989; Nicoletti et al., 1990), suggesting that glutamate receptors linked to $\left[\mathrm{Ca}^{2+}\right]_{i}$ mobilization might be transiently expressed to regulate gliogenesis.

The functional implications of adrenergic receptor stimulation and $\left[\mathrm{Ca}^{2+}\right]_{\mathrm{i}}$ signals

Activation of astrocyte $\alpha_{1}$-adrenergic receptors results in both $\left[\mathrm{Ca}^{2+}\right]_{i}$ mobilization and stimulation of protein kinase $\mathrm{C}(\mathrm{PKC})$. Such stimulation could, therefore, activate a myriad of $\left[\mathrm{Ca}^{2+}\right]-$ dependent or PKC-dependent processes. Increases in astroglia $\left[\mathrm{Ca}^{2+}\right]_{i}$ may activate $\left[\mathrm{Ca}^{2+}\right]_{i}$-dependent $\mathrm{K}$ channels (Quandt and MacVicar, 1986; Butt et al., 1990), thereby increasing the $\left[\mathrm{K}^{+}\right]_{o}$ spatial buffering capacity of astrocyte networks. Localized stimulation of astrocytes by adrenergic synapses could initiate regenerating $\left[\mathrm{Ca}^{2+}\right]_{i}$ waves analogous to those evoked by glutamate in culture (Cornell-Bell et al., 1990; Dani et al., 1992). $\alpha_{1}$ receptor stimulation of PKC (Pearce et al., 1985; El-Etr et al., 1992) could evoke prostanoid synthesis (Jeremy et al., 1987), nitric oxide production (Agullo and Garcia, 1991; S. Murphy et al., 1993), trigger expression of c-fos (Cordorelli et al., 1989) and other early response genes (Arenander ct al., 1989), modulate gap junctional communication (Giaume et al., 1991; Enkvist and MacCarthy, 1992), induce morphological changes (Mobley et al., 1986), modulate neurotransmitter uptake (Gomeza et al., 1991), and increase glycogenolysis (Pearce et al., 1988). This latter effect is of particular interest given that the majority of brain glycogen is stored in astroglia (Phelps, 1972) and that $\alpha$-adrenergic agonists promote glycogenolysis from astroglia in vitro (Cambray-Deakin et al., 1988). Also, increases in adrenergic activity (spike activity of the locus coeruleus) are initiated by hypoglycemia (Morilak et al., 1987). 
We have studied transmitter-evoked $\left[\mathrm{Ca}^{2+}\right]_{i}$ signaling in astrocytes within intact brain slices to examine these phenomena under conditions where cell phenotype would likely reflect that in vivo. Under these conditions, astrocytes responded to $\alpha_{1}$-adrenergic receptor stimulation with kinetically complex $\left[\mathrm{Ca}^{2+}\right]_{\text {i }}$ transients, while glutamate was not effective. The presence of $\left[\mathrm{Ca}^{2+}\right]_{i}$ increases evoked by adrenergic agonists coupled with anatomical evidence for astrocytes as a major target of the adrenergic system in vivo (Stone and Ariano, 1989) indicate that this is a major form of neuron-astroglial communication. In contrast, the role of glutamate as a neuron-to-astroglial signaling factor in the mature hippocampus must be re-evaluated.

\section{References}

Agullo L, Garcia A (1991) Norepinephrine increases cyclic GMP in astrocytes by a mechanism dependent on nitric oxide synthesis. Eur J Neurosci 206:343-346.

Ahmed Z, Lewis CA, Faber DS (1990) Glutamate stimulates release of $\left[\mathrm{Ca}^{2+}\right]$ from internal stores in astroglia. Brain Res 516:165-169.

Akerman KEO, Enkvist MOK, Holopainen I (1988) Activators of protein kinase $\mathrm{C}$ and phenylephrine depularize the astrocyte membrane by reducing $\mathrm{K}^{+}$permeability. Neurosci Lett 92:265-269.

Andrew RD, MacVicar BA (1994) Imaging cell volume changes and neuronal excitation in the hippocampal slice. Neuroscience 62:371383.

Aoki C (1992) $\beta$-adrenergic receptors: astrocytic localization in the adult visual cortex and their relation to catecholamine axon terminals as revealed by electron microscopic immunocytochemistry. J Neurosci 12:781-792.

Arenander AT, de Vellis J, Herschman HR (1989) Induction of c-fos and TIS genes in cultured rat astrocytes by neurotransmitters. J Neurosci Res 24:107-114.

Arslan P, Di Virgilio F, Beltrame M, Tsien RY, Pozzan T (1985) Cytosolic $\mathrm{Ca}^{2+}$ homeostasis in Ehrlich and Yoshida carcinomas. A new, membrane-permeant chelator of heavy metals reveals that these ascites tumour cell lines have normal cytosolic free $\mathrm{Ca}^{2+}$. J Biol Chem 260:2719-2727.

Barres BA, Chun LLY, Corey DP (1989) Calcium currents in cortical astrocytes: induction by cAMP and neurotransmitters and permissive effect of serum factors. J Neurosci 9:3169-3175.

Barres BA, Chun LLY, Corey DP (1990) Ion channel expression by white matter glia: the type-1 astrocyte. Neuron 5:527-544.

Bowman CL, Kimelberg HK (1984) Excitatory amino acids directly depolarize rat brain astrocytes in primary culture. Nature 311:656659.

Bowman CL, Kimelberg HK (1987) Pharmacological properties of the norepinephrine-induced depolarization of astrocytes in primary culture: evidence for the involvement of an $\alpha_{1}$-adrenergic receptor. Brain Res 423:403-407.

Brown J, Doxey JC, Handley S (1980) Effects of $\alpha$-adrenergic agonists and antagonists and of antidepressant drugs on pre- and postsynaptic $\alpha$-adrenoreceptors. Eur J Pharmacol 67:33-40.

Burnard DM, Critchton SA, MacVicar BA (1990) Electrophysiological properties of reactive glial cells in the kainate-lesioned hippocampal slice. Brain Res 510:43-52.

Butt AM, Hargittai PT, Lieberman EM (1990) Calcium-dependent regulation of potassium permeability in the glial perineurium (bloodbrain barrier) of the crayfish. Neuroscience 38:175-185.

Cambray-Deakin M, Pearce B, Morrow C, Murphy S (1988) Effects of neurotransmitters on astrocyte glycogen stores in vitro. J Neurochem 51:1852-1857.

Clark B, Mobbs P (1992) Transmitter-operated channels in rabbit retinal astrocytes studied in situ by whole-cell patch clamping. J Neurosci 12:664-673.

Condorelli DF, Kaczmarek L, Nicoletti F, Arcidiacona A, Dell-Albani P, Ingrao F, Magri G, Malaguarnera L, Avola R, Messina A, Stella AM (1989) Induction of protooncogene fos by extracellular signals in primary glial cell cultures. J Neurosci Res 23:234-239.

Connors BW, Benardo LS, Prince DA (1984) Carbon dioxide sensitivity of dye-coupling among glia and neurons of the neocortex. J Neurosci 4:1324-1330.

Cornell-Bell AH, Finkbeiner SM, Cooper MS, Smith SJ (1990) Glu- tamate induces calcium waves in cultured astrocytes: long-range glial signalling. Science 247:470-473.

Dani JW, Chernjavsky A, Smith SJ (1992) Neuronal activity triggers calcium waves in hippocampal astrocyte networks. Neuron 8:429440

Dave V, Gordon GW, MacCarthy KD (1991) Cerebral type 2 astroglia are heterogeneous with respect to their ability to respond to neuroligands linked to calcium mobilization. Glia 4:440-447.

de Barry J, Ogura A, Kudo Y (1991) $\mathrm{Ca}^{2+}$ mobilization in cultured rat cerebellar cells: astrocytes are activated by t-ACPD. Eur J Neurosci 3:1146-1154.

Delumeau JC, Tence M, Marin P, Cordier J, Glowinski J, Premont J (1991) Synergistic regulation of cytosolic $\mathrm{Ca}^{7+}$ concentration by adenosine and $\alpha 1$-adrenergic agonists in mouse striatal astrocytes. Eur J Neurosci 3:539-550.

Duffy S, MacVicar BA (1994) Potassium-depolarization evoked calcium influx in acutely isolated hippocampal astrocytes. Neuroscience 61:51-61.

Eberhard M, Ene P (1991) Calcium binding to fluorescent calcium indicators: calcium green, calcium orange and calcium crimson. Biochem Biophys Res Commun 180:209-215.

El-Etr M, Marin P, Tence M, Delumeau JC, Cordier J, Glowinski J, Premont J (1992) 2-Chloroadenosine potentiates the $\alpha_{1}$-adrenergic activation of phospholipase $\mathrm{C}$ through a mechanism involving arachidonic acid and glutamate in striatal astrocytes. J Neurosci 12: 1363-1369.

Enkvist MOK, McCarthy KD (1992) Activation of protein kinase C blocks astroglial gap junction communication and inhibits the spread of calcium waves. J Neurochem 59:519-526.

Enkvist MOK, Holopainen I, Akerman KEO (1989) $\alpha$-receptor and cholinergic receptor-linked changes in cytosolic $\mathrm{Ca}$ and membrane potential in primary rat astrocytes. Brain Res 500:46-54.

Fatatis A, Russell JT (1992) Spontaneous changes in intracellular calcium concentration in type-1 astrocytes from rat cerebral cortex in primary culture. Glia 5:95-104.

Finkbeiner SM (1992) Calcium waves in astrocytes-filling in the gaps. Neuron 8:1101-1108.

Finkbeiner SM (1993) Glial calcium. Glia 9:83-104.

Gathwaite J (1985) Cellular uptake disguises actions of L-glutamate on $\mathrm{N}$-methyl-D-aspartate receptors. With an appendix: diffusion of transported amino acids into brain slices. Br J Pharmacol 85:297-307.

Giaume C, Marin P, Cordier J, Glowinski J, Premont J (1991) Adrenergic regulation of intercellular communications between cultured striatal astrocytes from the mouse. Proc Natl Acad Sci USA 88:55775581.

Glaum SR, Holzwarth JA, Miller RJ (1990) Glutamate receptors activate $\mathrm{Ca}^{2+}$ mobilization and $\mathrm{Ca}^{2+}$ influx into astrocytes. Proc Nat Acad Sci USA 87:3454-3458.

Gomeza J, Casado M, Gimenez C, Aragon C (1991) Inhibition of highaffinity $\gamma$-aminobutyric acid uptake in primary astrocyte cultures by phorbol esters and phospholipase C. Biochem J 275:435-439.

Gutnick MJ, Connors BW, Ransom BR (1981) Dye-coupling between glial cells in the guinea pig neocortical slice. Brain Res 213:486492

Iwakura K, Hori M, Watanabe Y, Kitabatake A, Cragoe EJ, Yoshida $\mathrm{H}$, Kamada T (1990) $\alpha_{1}$-adrenoceptor stimulation increases intracellular $\mathrm{pH}$ and $\mathrm{Ca}^{3+}$ in cardiomyocytes through $\mathrm{Na}^{+} / \mathrm{H}^{+}$and $\mathrm{Na}^{+} / \mathrm{Ca}^{2+}$ exchange. Eur J Pharmacol 186:29-40.

Jabs R, Kirchhoff F, Kettenmann H, Steinhauser C (1994) Kainate activates $\mathrm{Ca}^{2+}$-permeable glutamate receptors and blocks voltage-gated $\mathrm{K}^{+}$currents in glial cells of mouse hippocampal slices. Pfluegers Arch 426:310-319.

Jahromi BS, Robitaille R, Charlton MP (1992) Transmitter release increases intracellular calcium in perisynaptic Schwann cells in situ. Neuron 8:1069-1077.

Jeremy J, Murphy S, Morrow C, Pearce B, Dandona P (1987) Phorbol ester stimulation of prostanoid synthesis by cultured astrocytes. Brain Res 419:364-368.

Juurlink BHJ, Hertz L (1985) Plasticity of astrocytes in primary cultures: an experimental tool and a reason for methodological caution. Dev Neurosci 7:263-277.

Koneintzko U, Muller CM (1994) Astrocyte dye coupling in rat hippocampus: topography, developmental onset and modulation by protein kinase C. Hippocampus 4:297-306. 
Kriegler S, Chiu SY (1993) Calcium signalling of glial cells along mammalian axons. J Ncurosci 13:4229-4245.

Lullmann H, Timmermans P, Ziegler A (1979) Accumulation of drugs by resting or beating cardiac tissue. Eur $\mathrm{J}$ Pharmacol 60:277-285.

MacVicar BA (1984) Voltage-dependent calcium channels in glial cells. Science 226:1345-1347.

MacVicar BA, Tse FWY (1988) Norepinephrine and cyclic adenosine $3^{\prime}: 5^{\prime}$-cyclic monophosphate enhance a nifedipine-sensitive calcium current in cultured rat astrocytes. Glia 1:359-365.

MacVicar BA, Hochman D, Delay MJ, Weiss S (1991) Modulation of intracellular $\mathrm{Ca}^{2+}$ in cultured astrocytes by influx through voltageactivated $\mathrm{Ca}^{2+}$ channels. Glia 4:448-455.

Milani D, Facci L, Guidolin D, Leon A, Skaper SD (1989) $\Lambda$ ctivation of polyphosphoinositide metabolism as a signal-transducing system coupled to excitatory amino acid receptors in astroglial cells. Glia 2:161-169.

Minneman KP, Johnson RD (1984) Characterization of Alpha-1 adrenergic receptors linked to $\left[\mathrm{H}^{3}\right]$ inositol metabolism in rat cerebral cortex. J Pharmacol Exp Ther 230:317-323.

Mobley PL, Scott SL, Cruz EG (1986) Protein kinase C in astrocytes: a determinant of cell morphology. Brain Res 398:366-369.

Morilak DA, Fornal CA, Jacobs BL (1987) Effects of physiological manipulations on locus coeruleus neuronal activity in freely moving cats. 111. Glucoregulatory challengc. Brain Res 422:32-39.

Mudrick-Donnon LA, Williams PJ, Pittman QJ, MacVicar BA (1993) Postsynaptic potentials mediated by GABA and dopamine evoked in stellate glial cells of the pituitary pars intermedia. J Neurosci 13: $4660-4668$.

Muller T, Moller T, Berger T, Schnitzer J, Kettenmann H (1992) Calcium entry through kainate receptors and resulting potassium-channel blockade in Bergmann glial cells. Science 256:1563-1566.

Muller W, Misgeld U, Heinemann U (1988) Carbachol effects on hippocampal neurons in vitro: dependence on the rate of rise of carbachol tissue concentration. Exp Brain Res 72:287-298.

Murphy S (1993) Astrocytes: pharmacology and function. Academic.

Murphy S, Simmons ML, Agullo L, Gargia A, Feinstein DL, Galea E, Reis DJ, Minc-Golomb D, Schwartz JP (1993) Synthesis of nitric oxide in CNS glial cells. Trends Neurosci 16:323-328.

Murphy TH, Blatter LA, Wier WG, Baraban JM (1993) Rapid communication between neurons and astrocytes in primary cortical culture. J Neurosci 13:2672-2679.

Nedergaard M (1994) Direct signaling from astrocytes to neurons in cultures of mammalian brain cells. Science 263:1768-1771.

Nicoletti F, Magri G, Ingrao F, Bruno V, Catania MV, Dell'Albani P, Cordorelli DF, Avola R (1990) Excitatory amino acids stimulate inositol phospholipid hydrolysis and reduce proliferation in cultured astrocytes. J Neurochem 54:771-777.

Parpura V, Basarsky TA, Liu F, Jeftinija K, Jeftinija S, Haydon PG (1994) Glutamate-mediated astrocyte-neuron signalling. Nature 369: 744-747.

Pearce B, Cambray-Deakin M, Morrow C, Grimble J, Murphy S (1985) Activation of muscarinic and of $\alpha_{1}$-adrenergic receptors on astrocytes results in the accumulation of inositol phosphates. J Neurochem 45: $1534-1540$.

Pearce B, Albrecht J, Morrow C, Murphy S (1986) Astrocyte glutamate receptor activation promotes inositol phospholipid turnover and calcium flux. Neurosci Lett 72:335-340.

Pearce B, Morrow C, Murphy S (1988) A role for protein kinase C in astrocyte glycogen metabolism. Neurosci Lett 90:191-196.

Phelps CH (1972) Barbiturate-induced glycogen accumulation in brain. An electron microscopic study. Brain Res 39:225-234.

Porter JT, McCarthy KD (1995) GFAP-positive hippocampal astrocytes in situ respond to glutamatergic neuroligands with increases in $\left[\mathrm{Ca}^{2+}\right]_{i}$. Glia 13:101-112.

Quandt FN, MacVicar BA (1986) Calcium activated potassium channels in cultured astrocytes. Neuroscience 19:29-41.

Ridet J-L, Rajaofetra N, Teilhac J-R, Geffard M, Privat A (1993) Evidence for nonsynaptic serotonergic and noradrenergic innervation of the rat dorsal horn and possible involvement of neuron-glia interactions. Neuroscience 52:143-157.

Robinson SR, Hampson ECGM, Munro MN, Vaney DI (1993) Unidirectional coupling of gap junctions between neuroglia. Science 262: 1072-1074.

Salm AK, MacCarthy KD (1989) Expression of beta-adrenergic receptors by astrocytes isolated from adult rat cortex. Glia 2:346-352.

Salm AK, McCarthy KD (1990) Norepinephrine-evoked calcium transients in cultured cerebral type 1 astroglia. Glia 3:529-538.

Salter MW, Hicks JL (1994) ATP-evoked increases in intracellular calcium in neurons and glia from the dorsal spinal cord. J Neurosci 14 $1563-1575$.

Sarantis M, Ballerini L, Silver RA, Edwards SM, Attwell D (1993) Glutamate uptake from the synaptic cleft does not shape the decay of the non-NMD $\Lambda$ component of the synaptic current. Neuron 11: 541-549.

Seguela P, Watkins KC, Geffard M, Descarries L (1990) Noradrenaline axon terminals in adult rat neocortex: an immunocytochemical analysis in serial thin sections. Neuroscience 35:249-264.

Shao Y, Enkvist K, McCarthy K (1993) Astroglial adrenergic receptors. In: Astrocytes: pharmacology and function (Murphy S, ed). New York: Academic.

Somogyi P, Eshhar N, Teichberg VI, Roberts JDB (1990) Subcellular localization of a putative kainate receptor in Bergmann glial cells using a monoclonal antibody in the chick and fish cerebellar cortex. Neuroscience 35:9-30.

Sontheimer H, Waxman SG (1993) Expression of voltage-activated ion channels by astrocytes and oligodendrocytes in the hippocampal slice. J Neurophysiol 70:1863-1873.

Sontheimer H, Waxman SG, Ransom BR (1991) Relationship between $\mathrm{Na}^{+}$current expression and cell-cell coupling in astrocytes cultured from rat hippocampus. J Neurophysiol 65:989-1002.

Steinhauser C, Jabs R, Kettenmann H (1994) Properties of GABA and glutamate responses in identified glial cells of the mouse hippocampal slices. Hippocampus 4:19-39.

Stone EA, Ariano MA (1989) Are glial cells targets of the central noradrenergic system? A review of the evidence. Brain Res Rev 14: 297-309.

Takato M, Goldring S (1979) Intracellular marking with lucifer yellow $\mathrm{CH}$ and horseradish peroxidase of cells electrophysiologically characterized as glial in the cerebral cortex of the cat. J Comp Neurol 186:173-188.

Zhao Z, Code WE, Hertz L (1992) Dexmedetomidine, a potent and highly specific alpha $a_{2}$ agonist, crokes cytosolic calcium surge in astrocytes but not in neurons. Neuropharmacology 31:1077-1079. 